\title{
Navigating the Newstream: Recent Critical Scholarship in International Law
}

\author{
Deborah Z Cass
}

Deborah Z Cass, 'Navigating the Newstream: Recent Critical Scholarship in International Law' (1996) 65 Nordic Journal of International Law 341, 341383, doi.org/10.1163/15718109620294924 <https://heinonline.org/HOL/ LandingPage?handle=hein.journals/nordic65\&div $=26 \& \mathrm{id}=\&$ page $=>$

Reproduced with the permission of the Nordic Journal of International Law.

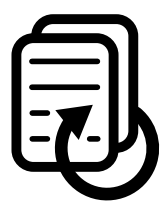





\title{
Navigating the Newstream: Recent Critical Scholarship in International Law
}

\author{
DEBORAH Z. CASS* \\ Lecturer in Law. Australian National University, Canberra
}

\section{Introduction}

Generations of legal scholars have reinvented their fields by a ritual overthrowing of their predecessors ${ }^{1}$ and one group within the current crop of international lawyers is no exception. These lawyers, who label themselves as Newstream, ${ }^{2}$ are presently involved in a theory battle with those the new scholars label, somewhat negatively, as Mainstream. ${ }^{3}$ This otherwise esoteric battle is interesting because it coincides with a changed perception about

* LL.B (Hons) University of Melbourne 1989, LL.M Harvard University 1995, currently S.J.D. candidate Harvard University. I would like to thank Susan Marks, David Kennedy and Gerry Simpson for their invaluable comments on earlier drafts.

'See e.g. the Realist school of American legal thought which was in part a project aimed at creating a new way of thinking in contradistinction to what it labeled "formalism". For a discussion of the realist critique as a response to formalism see William W. Fisher, "The Development of Modern American Legal Theory and the Judicial Interpretation of the Bill of Rights", in M. Lacey \& K. Haakonssen, (Eds), A Culture of Rights (1991).

2 I will use the term "Newstream" to discuss work which has been referred to variously as "New Stream" or part of a body of "New Approaches". See David Kennedy, "A New Stream of International Law Scholarship", 7 Wis. Int L. J. 1, (1988) [hereinafter New Stream] and David Kennedy \& Chris Tennant, "New Approaches to International Law: A Bibliography", 35 Harv. Int. L. J. 417, (1994) [hereinafter New Approaches]. International legal scholarship which defined itself as "New Stream" first appeared around 1980: see Nigel Purvis, "Critical Legal Studies in Public International Law", 32 Harv. Int. L. J. 81, 89 (1991) at note 41. It has expanded considerably since then. The proportion of analyses which were so defined in 1980 was relatively small. A 1991 survey of the field noted three book length expositions and just over a dozen contributions in all: Id. At 89 and 91. Cf. In 1988 David Kennedy listed 17 scholars as pursuing "critical projects" in the field: Kennedy, New Stream, id., at 2. Three years later the number of analyses identified as Newstream had increased to some four bundred and fifty: Kennedy and Tennant, id., at 431-460.

${ }^{3}$ In this article Mainstream is intended to refer to a body of scholars who have dominated the field for the last twenty-five years. It does not indicate any homogenous category but covers a number of different theoretical approaches including realist (Schwarzenberger, Weil, Watson), classicist (Fitzmaurice), and liberal-humanitarian (Henkin, MacDougall, Falk). 
the role of international law in structuring and regulating international public order. A once moribund international rule of law is assumed to have been reinvigorated by current events. The resuscitation of international law is accompanied by an optimism arising out of a perceived end to the polarized bloc politics of the late twentieth century. Actions in the Gulf and in Somalia are seen as evidence of the international community's will to collectively respond to threats to international peace and security. But that optimism is also tempered by a strange uncertainty about ordering the international plane. Besides being somewhat quelled by the experiences of Somalia and the former Yugoslavia, post Cold War confidence in intemational law has been replaced by a muted anxiety about its limitations. This anxiety focuses on questions which seem to have become more, rather than less, difficult to answer since the resolution of superpower politics. What is the role of the weakened nation state in the new regional arrangements of world order? How will human rights regimes overcome the chasms of cultural difference between societies? What is "culture" anyway? What is the nature of the relationship between international trade regulation and local governance? Can reconstituted units of failed federations accommodate disparate ethnic interests? It is in the service of answering these dilemmas that the new brand of legal scholarship has risen to prominence, claiming to challenge the certainties of the old. This article is about that challenge, and the attempt by the new scholars to reconceptualize the idea of what is international law.

The article is inspired by the sense that, to date, the battle between the Newstream and the Mainstream has been a rather detached, disengaged affair, and that in particular, the Mainstream has failed to respond meaningfully to Newstream critique. Instead the Newstream has been anxiously dismissed as overly theoretical or willfully obtuse. ${ }^{4}$ Here I refine and explore some of the Newstream ideas which have invigorated the discipline and have the potential

\footnotetext{
${ }^{4}$ Despite the industry of Newstream writers, supra note 2, and the appearance of two lengthy survey articles (Purvis, supra note 2), book reviews (see e.g., Ian Scobbie, "Towards the Elimination of International Law: Some Radical Skepticism about Skeptical Radicalism", Brit. Y.B. Int'l. L. 339 (1990) frequent citation in scholarly joumals by writers sharing similar concerns, and attention at international law conferences, (e.g., American Society of International Law Annual General Meeting 1994, panel on Theoretical Perspectives on Sovereignty, comments by Martii Koskenniemi and Karen Knop), to date, the new analyses have been largely ignored, or at least superficially treated, in recently revised publications of the traditional discipline. See e.g. a recently revised standard Casebook used in American law schools, Louis Henkin, Richard Pugh, Oscar Schachter, Hans Smit, International Law Cases and Materials, 3rd ed., (1993) which devotes two pages to "intemational law and the critical legal studies movement" id. at 48-49, four pages to "feminist perspectives" id. at $43-47$, and occasionally refers to specific writers associated with Newstream such as Philip Allot, id. at 16. Other Mainstream scholars engage only very briefly with the critique in order to dismiss it. See e.g., Rosalyn Higgins, Problems and Process: International Law and How We Use It, (1994) esp. Ch. 1 "Nature and Function of International Law."
} 
to create a productive dialogue between the bearers of the international tradition and its challengers. ${ }^{5}$ I intend to show how this should lead to a gradual recasting of the field.

There is little doubt that a large body of compelling work has now been written, associated with the rubric of Newstream, and that its continued neglect by the Mainstream risks stultifying the field and prevents the development of a more nuanced and responsive international legal theory. The Newstream critique's major strength, its sense of a mission to create a new international law, risks being blunted by the lack of dialogue between the two approaches. Moreover, as pedagogical tools, the Newstream writings are invaluable because they offer plausible explanations of international law making, interpretation and application, at a point in time in which traditional understandings about law have been questioned by (post)modern insights into cultural fragmentation, the making of history and the role of language in law. The work also echoes a widespread interdisciplinary interest in language and its effect on the structure of ideas.

Despite these strengths Newstream scholars do not exploit the critique's potential because they often fail to make explicit evaluative choices. If they perceive law as simply a variable set of argumentative possibilities, these possibilities are not being used to effect change. There are problems internal to the critique as well, for example its often condescending and reductive tone, and its occasionally derivative and abstract theorizing.

I have thus positioned my own critique at the borderline in the hope that it will enable both sides to explore each others territory. Putting to one side the reality that at least some Mainstream and Newstream writers perceive their positions as antithetical, I will assume that any conversation between

\footnotetext{
${ }^{5}$ In addition to the quantitative impact of the work, it is having a substantive effect on academic and practitioners alike. An anecdotal survey of some international law teachers indicates that many use the writers discussed here in their teaching. International law texts now include references, albeit somewhat cursory, to these writings. Writers not formally identified with the approach use the various techniques identified above. See e.g., Patrick Thomberry in Christian Tomuschat, The Modern Law of Self-Determination 1993 (analyzing self-determination law as a "metalanguage" and proposing a reconstruction based on a new conception of the relationship between the State and its sub-groups). Practitioners in law firms, departments of state around the world, corporations, and non-government organizations are increasingly schooled in these methods of analysis. In some cases the experience of these practitioners is channeled back into the academic scholarship. See e.g., Meana M. Porras, "The Rio Declaration: A New Basis for International Cooperation", in Phillippe Sands, Greening International Law, (1993) (arguing that the Rio Declaration represents a compromise between the interest in development of developing states and the interest of the West in environmental protection. Porras acted as govemment representative at the Rio Conference). The result of these developments has been to extend the effect of the work, so that it is beginning to reach into the public and private sectors, as well as the academy. Accordingly there is need to incorporate these materials more thoroughly into mainstream teaching and research.
} 
theoretical positions is good for international law, because it generates a deeper understanding of what the discipline entails. My starting premise is that Mainstream scholars ought to pay greater heed to the transformative potential of some of the work of the Newstream, and the latter should acknowledge their continuing debt to the scholars who have preceded them, and continue to engage with that work. I will therefore set out in my paper what I believe to be the main arguments of Newstream work. By offering one translation of a sample of the recent scholarship I hope to demonstrate its richness and creativity; to provide a point of entry for dialogue between the perspectives; and to promote the use of Newstream work as a valuable source of information and analysis for Mainstream scholars.

\section{Structure and Overview of Paper}

The Newstream, positioning themselves in opposition to the Mainstream, have challenged the international law tradition at three levels. Section 3 of this paper is devoted to discussing the underlying conceptual challenge of Newstream work, Section 4 its methods, and Section 5 its strategies. In a concluding section, Section 6, I examine some recurring problems with the critique. Before commencing I will briefly sketch the three challenges: conceptual, methodological, and strategic.

Newstream writers are making a conceptual claim about Mainstream scholarship (Section 3) which has three parts. First, the Newstream regard Mainstream international law as having adopted a complacent approach toward questions of how to define culture and differences between cultures (Section 3.1). This is exemplified in the arid debates over self-determination and cultural relativism. By contrast Newstream writers claim that the way in which culture is defined determines the legal rule which ensues, and that the meaning of what is culture is thus primary to the doctrines which have evolved. Second, they contend that Mainstream international law represents itself as an account of history as progress in which the doctrine of sovereignty develops from an uncertain principle of naked power distribution to a more formal, regulable legal mechanism (Section 3.2). Newstream accounts suggests that the story is more complex and that sovereignty can be re-interpreted in the light of different readings of the historical development of international law, in a manner which would inevitably unsettle interpretations of important doctrines such as acquisition, or territorial integrity. Third, they argue that Mainstream scholars have maintained a fiction that law-making can be reduced to either custom (a reflexive process of locating and amalgamating the practice and belief of states), or agreement and the drafting of new treaties, and so have failed to sufficiently take into account contemporary theoretical insights relating to 
language and representation (Section 3.3). If law is constituted by language rather than simply objective behavior and belief, then its foundations are less certain and its reconstitution is not only possible but obligatory. In short, the Newstream argues that Mainstream literature relies upon an untenable set of ideas about culture, sovereignty, and law-making.

In addition to these substantive, conceptual claims the Newstream argues that the Mainstream has a limited approach to method. So the second level of challenge is methodological provoking Newstream writers to experiment with different analytical devices (Section 4). First, new approaches method often locates and dissects twinned conceptual oppositions underlying history, sovereignty and culture, thereby revealing the unstable and contingent nature of the law which they support (Section 4.1). Second, Newstream writings represent international actors as being engaged on a highly personal quest, thereby undermining the notional objectivity and formality of international rules (Section 4.2). The device of the quest also produces an evocative descriptive framework, a personal and personally revealing account of law, and a mechanism to explore the internal contradiction between international law's idealism and its ordinariness. Finally, Newstream work uses language in ways which emphasize the conceptual and methodological themes just noted (Section 4.3).

Third, there is a strategic level to the challenge (Section 5). Here Newstream scholars reinvigorate pre-existing reform strategies, in an attempt to shift the emphasis of lawmaking from one of reform to radical reconceptualization. This is accomplished by incorporating perspectives foreign to the discipline and hitherto absent, and by situating legal problems more fully in their political and cultural context (Section 5.1); by provocative rewritings of doctrinal history (Section 5.2); and by integrating political considerations into legal analysis (Section 5.3).

Finally in Section 6 I argue that while these Newstream challenges could be transformative tools of changing law their potential is largely unrealized. Section 6 extends my critique by highlighting previously identified recurring problems with the analyses, namely their lack of concretization, reductionism and tendency toward condescension.

\section{The Newstream Conceptual Challenge to Mainstream International Law}

This part of the essay will examine the way Newstream writings are redefining some foundational concepts of international law. The three themes I focus on are: culture, the relationship between history and sovereignty and the role of language in the constitution of legal doctrine. 


\subsection{Culture}

The first conceptual theme that features strongly throughout this body of this work is a concern with what constitutes culture. This is presented by the Newstream writers as a challenge to what they perceive as international law's traditional complacency when describing different groups of people, or modes of social, political and economic organization.

Much of the Newstream scholarship begins from the premise that definitions of culture are central to the way in which international law has been constituted, and that the meanings used in Mainstream literature operate to include certain ideas and groups of people and exclude others. So for example, a first group of Newstream writers interested in culture contend that representations of indigenous people in Mainstream international law have tended to mimic the standard stereotypes. They have been depicted as backward, under-developed, or more latterly, noble and thereby excluded from the development of law. ${ }^{6}$ Moreover, this portrayal is represented as an inevitable result

\footnotetext{
${ }^{6}$ See e.g., Chris Tennant "Indigenous Peoples International Institutions and the International Legal Literature from" 1945-1993, 16 Human Rights Quarterly 1, 7 (1994) discussing the relationship between the representation of indigenous people in international legal literature and international law's treatment of them. He argues that there is a connection between the images in the literature and international law's treatment of them. He argues that there is a connection between the images in the literature and the practices of law. Indigeneous peoples are represented in the international legal literature as either "ignoble" or noble and that both representations affect the way in which law responds to their situation. On this view, cultural (mis)representations determine law. So in the period to 1945 indigenous peoples were represented as "ignoble", located in the past, lacking and incapable of exercising political responsibility. At the same time international law emphasized strategies of technical assistance, development and assimilation, in order to bring them into the present. More recently the international legal literature has represented indigenous people as "noble", as part of a communitarian lifestyle, in harmony with the environment and detached from modernity. Accordingly current legal strategies stress "flexible concepts of self-determination and autonomy", in order to transcend the failures of modernity, Id. at 24 . In both cases international processes, doctrines, and institutions are responding to representations of indigenous people and not to indigenous peoples themselves. Moreover, the different representations actually corresponded to the goals of that particular period of law. When assimilation was considered a legitimate goal of law, indigenous people were portrayed as "ignoble" and in need of civilizing; when integration lost its cachet and there was disillusionment with Western legal solutions, indigenous people were depicted as "noble" and encouraged to remain separate from Western culture. Similarly Ileana Porras, in an article on terrorism, argues that international law's definition of terrorism frequently depends upon images of Orientalism which are constructed to suit law's need to exclude this form of violence from the range of the "normal" rules: lleana Porras, "On Terrorism: Reflections on Violence and the Outlaw", in D. Danielsen and Karen Engle Eds., After Identity: A Reader in Law and Culture (1995). Hence a man charged with acts of terrorism is described in the press as wearing a suit "billowing in the wind" Porras, id. 304, reminiscent of Lawrence of Arabia imagery. The depiction of terrorist actors as "other" enables their acts to be demonized as a form of violence beyond that which is "normal" and thus the ordinary rules of international law, say in relation to the laws of war, or criminal law cannot apply. The construction of cultural stereotypes determines a particular set of international rules.
} 
of culture and so, according to the Newstream, only a concerted rewriting of Mainstream cultural depictions will lead to changes in the actual practice of law.

Not all Newstream writers confront the question of culture in the same manner. There is a marked division between those who claim that the Mainstream literature has produced a Westernized view of different cultural groups, but that this depiction can be reconstructed, and, those who argue that the foundations of international law are so saturated with partial ideas about culture, that they cannot be reconstructed.

A group representing the first viewpoint argue that international legal culture has been fashioned out of a Western set of values, ${ }^{7}$ but ultimately they maintain that law can recognize its own subjectivity and transcend $\mathrm{it}^{8}$ by one of two methods. International Law could become more conscious of the legal viewers' own perspective, ${ }^{9}$ or it might apply legal rules in a manner which recognizes the particular context of the group subject to the rule. ${ }^{10}$ In sum, according to this first group of Newstream scholars, definitions of culture, although skewed by current Mainstream work, can be reassembled in such a way so as to incorporate into law the particular practices of the exclud-

\footnotetext{
${ }^{7}$ See e.g., an exploration of the exclusionary power of Western cultural assumptions, on law in Rosemary Coombe, "The Properties of Culture and the Politics of Possessing Identity: Native Claims in the Cultural Appropriation Controversy", in D. Danielsen and K. Engle Eds., After Identity: A Reader in Law and Culture (1995). Coombe's focus is the development of new forms of legal protection for the cultural property of indigenous peoples. Cultural property protection is based on the European "art/culture system" which excludes an indigenous understanding of ownership and identity. Moreover, this criticism applies to both traditional copyright law, and to the emerging laws of cultural property protection which purport to protect group rights. So, for example, both the copyright protection accorded Picasso's use of an indigenous mask and newer forms of collective cultural protection legislation are based on the same Western concept of "possessive individualism": id. at 255 . What is left out of both regulatory styles is the sense that both ownership and collective identity carry quite different and specific meanings for indigenous peoples. Ownership in an indigenous sense, for example, may include a bundle of ideas which cannot be simply directly translated into new Western forms of law. Hence she argues, the structure of Western law, steeped in cultural assumptions derived from its own art/culture system, precludes the creation of new forms of legal protection about indigenous art, ownership and identity.

${ }^{8}$ See, e.g., Frankenberg who argues that comparative lawyers are blinded by their own subjectivity: Gunter Frankenberg, "Critical Comparisons: Rethinking Comparative Law", 26 Harv. Int. L. J. (1985) 411. He claims that comparative lawyers fail to recognize that their own perspectives play a significant part in the way they view other cultures: id. at 441 . Moreover given this subjectivity, comparative law actually reveals more about the culture from which the comparativist belongs, than about the legal system under investigation.

${ }^{9}$ Id. at $\mathbf{4 4 2 .}$

${ }^{10}$ Coombe, supra note 7. Coombe's proposal to overcome this problem, is to "listen[...] to native claims in context": id. at 266 . She argues that in order to develop law reflecting indigenous ways of art and culture, it will be necessary to undertake a highly specific and contextualized form of investigation into the practices of the peoples involved. Only by adopting such a localized approach will laws emerge which accommodate the concerns of indigenous peoples.
} 
ed groups resulting in a new international law which is more contextual, comprehensive and ultimately more expressive of diverse cultures.

How effective is this form of critique? The first form argues for reconstruction. However given the underlying premise of the Newstream writers that Western social, political and economic organization dominates legal developments, it is difficult to see how law can simply transcend those limits by "listening in context." "11 The very hegemonic nature of definitions of culture will tend to work against this solution. It is unlikely, if not inconsistent, that on the one hand European culture precludes the formation of law responsive to indigenous people, and on the other to claim that if law "listens" harder, European culture can be overcome. Moreover, it is contradictory to criticize Mainstream scholars who purportedly attempt to distance themselves from their own cultural stereotyping and yet then argue that all lawyers should learn to "transcend perspective". ${ }^{12}$ On the one hand we are entreated to "recognize we are participants of one culture and observers of another"13 and on the other, that we can be released from the "all encompassing grip of the habit of our own truth." ${ }^{14}$ Is it possible to recognize subjectivity and transcend it simultaneously? If one accepts the first premise, namely that as lawyers we are trapped in our own cultural vision, then it seems problematic to overcome that vision, simply by an act of will. Although there is something appealing about the possibility that knowing who we are may lead to changing what we do, it seems likely that it will take more than mere desire to achieve it.

Ultimately this first group of Newstream writers effectively exposes the role of culture in determining legal practices, but their proposals to alter it are internally contradictory. This criticism may not however be fatal in the long term. Obviously under certain conditions, and over time, concepts and ideas which are beyond law's parameters are gradually incorporated, otherwise law would remain in a form of statis. Nevertheless it would seem that in order for the argument to have real force it is first necessary for these Newstream writers to speculate as to what are those conditions and how change can occur. How can contextualized listening lead to change? In what circumstances and by what mechanisms is it likely to occur? What is the appropriate context? The claim for contextualization is, to date, too thin to support a changed practice.

\footnotetext{
"Id. at 266.

${ }^{12}$ Frankenburg, supra note 8 at 442 . Frankenburg acknowledges that no-one can "dispose[.]" of their "cognitive history" or "baggage of assumptions", id. at 443 , yet he still ultimately advocates exactly just that, the only difference being that the actor does so self-consciously.

${ }^{13} \mathrm{Id}$.

${ }^{14}$ Id. at 454.
} 
While the first Newstream group advocates a redefinition of culture by either recognizing Mainstream stereotyping of cultural groups, or better contextualizing legal problem solving, or transcendence of subjectivity and other acts of will, the second group, which I now discuss, is skeptical of ever achieving these goals. ${ }^{15}$ This second group of Newstream writers are not so sanguine about reforming the current law. For them international law does not simply rely on culture, international law is culture. ${ }^{16}$ By implication, international law cannot transcend culture by recognizing group difference. It cannot undo constructed notions of culture, because the notion of culture inheres in what international law is. According to the second group of writers, the construction of culture is not only the result of human agency in creating stereotypes but results from the structures of international law, its language and its history. ${ }^{17}$

\footnotetext{
${ }^{15}$ The polarity within Newstream work reflects an irony which dogs much contemporary scholarship: at the same time that the critique of culture is strongest in some quarters, the embrace of difference is at its peak in others, even within the same project: See discussion of Arjun Appadurai, "Disjuncture and Difference in the Global Cultural Economy", 2 Pub. Culture (1990) 1.

${ }^{16}$ See, e.g., Annelise Riles discussion of the question of whether it is possible for law to ever overcome the categories of culture: Annelise Riles, "Note: Aspiration and Control: International Legal Rhetoric and the Essentialization of Culture", 106 Harv. L. Rev. 723 (1993) [hereinafter Aspiration and Control]. She argues that nineteenth century international law was built upon essentialized versions of European and non-European culture. Moreover, so dependent was law on these essentialized notions, that international law was collapsed into culture, even though it projected itself as separate and law-like. Culture as law came in two forms. In one case it manifested itself as a mechanism for ordering non-European peoples by requiring them to aspire to standards of European-ness, in order to be included within existing categories of law. Thus non-Europeans aspired to own territory in order to prove statehood, because a state without territory was like a man without clothes: id. at 733 quoting T. J. Lawrence, International Problems and Hague Conferences (1908). The other manifestation of culture as law was to order non-Europeans by controlling then in a "dizzying catalog of colonial topics", id. at 729 , according to racial differences and political organization. Both manifestations relied on culture. In one law offers the possibility of assimilation, in the other it offers the threat of exclusion.

${ }^{17}$ See, e.g., Antony Anghie who shares Riles' skepticism about the conundrum of law and culture, yet whose focus is on the role of language and history: Antony Anghie, Constructing the Nation State: Colonialism and the Making of International Law (1994), (unpublished S.J.D. dissertation, Harvard University, on file with author). Anghie claims international legal doctrine has developed largely in response to colonialism. Many of the major developments in relation to acquisition of territory, sovereignty and personality, for example, are informed by, and infused with the imperatives of colonialism. He argues that the entire language of international law was based on a complex taxonomy which separated "uncivilized from civilized" in order to justify inclusion and exclusion in full membership of the international system: Id. at 6 041-054. European notions of culture, defining everything from political organizations, to sexual practices, were used to denote "civilized" and exclude all else. However in order to treat with those outside the model of civilization, international law had also to create ways that the "uncivilized" could become objects, (but not subjects) of the system. Anghie develops the notions of "calibrated recognition", id., at 6068 , to describe the process by
} 
The second group argues that the very nature of international law as culture may preclude any possibility of modifying international law to make it more responsive to different cultures. Most importantly they argue that international law is inherently a European cultural form, ${ }^{18}$ and that these forms continues to pervade thinking, even amongst those who attempt to deconstruct law. ${ }^{19}$ In one example Mainstream international law is depicted as the cultural language of nineteenth century colonialism, ${ }_{9}^{20}$ and so language, culture and the formation of laws are therefore inextricably connected. Moreover if this story of the genesis of major doctrines of international law is correct, then those same cultural considerations continue to inform law-making and its functioning. Hence inbuilt and structural cultural biases will not simply be overcome by contextualization, or transcendence of perspective. What distinguishes the second group of Newstream writers from the first then is their belief that the very structure of international law precluded, and continues to preclude any way of moving beyond these cultural categories.

While the two viewpoints are partially persuasive, they both leave unanswered the question of how international law can be loosened from the particular cultural moorings it has acquired over time and which are now represented in Mainstream literature. Can the different cultural settings present in the twentieth century inspire a different international legal language? Will the post-colonial culture engender a post-colonial law in the same way that colonial culture produced colonial law? And is it possible for any universal system of international law to incorporate competing cultural considerations? Some of these critical issues are taken up by other Newstream writers who adopt an explicitly feminist perspective.

Their response has been to focus on a specific issue and document the difficulties it raises in recasting a more culturally sensitive international law. This has been done in relation to clitoridectomy, ${ }^{21}$ and the wearing of the veil $^{22}$ in order to demonstrate the important observation that feminist con-

which non-European groups werc kept out of international law membership but sufficiently recognized, (by personality doctrine and sovereignty/property distinctions for example), so that Europeans could trade with them, make unequal treaties with them and acquire their land. "'[T] 061 , and disempowerment because of the conjunction of civilization and sovereignty.

${ }^{18}$ Riles, Aspiration and Control, supra note 16.

${ }^{19}$ See e.g. Riles' discussion of David Kennedy's and Anthony Carty's treatment of culture: Riles id. at note 81 .

${ }^{20}$ Anghie, supra note 17.

${ }^{21}$ Karen Engle, "Female Subjects of Public International Law: Human Rights and the Exotic Other Female", 26 New Eng. L. Rev. 1509 (1992) [hereinafter Female Subjects].

${ }^{22}$ Lama Abu-Odeh, "Post-Colonial Feminism and the Veil: Considering the Differences", 26 New England L. R. 1527 (1992). 
ceptions of what is (women's) culture are precarious and diffuse. ${ }^{23}$ These studies therefore indicate that it will be even more problematic to develop an international law reflecting post-colonial culture, both where there are no clear categories of culture and where different cultural considerations, such as gender and religion, contradict and overlap. ${ }^{24}$ While not offering any neat solutions, these Newstream writings represent an advance upon the way the debate is conducted in Mainstream literature where it tends to devolve into an irresolvable exchange about whether international law should apply universal standards or be set according to local or regional needs. The difference here is that these Newstream writers intersect and oppose gender and culture in an attempt to move the debate beyond the simple observation that when trying to construct a more inclusive international law, previously excluded cultural factors come into conflict with each other. In contrast these works attempt to

\footnotetext{
${ }^{23}$ Karen Engle explores and criticizes the way different feminist critiques of international human rights, identify and assimilate women's concems: Karen Engle, "International Human Rights and Feminism: When Discourses Meet", 13 Mich. J. of Int'l L. 517 (1992) thereinafter International Human Rights]. She categorizes feminist approaches according to how they incorporate a conception of womens' culture into human rights. A three-layered typology is produced consisting of doctrinalists, institutionalists and extemal critics. "Doctrinalists" work within the framework of the existing doctrine to change and improve it, id. at 522. Hence the prohibition against torture contained in various human rights instruments can be extended to a prohibition against violence in the home, through a process of reinterpretation. "Institutionalists" focus their work on the processes of law-making advocating greater participation of women ultimately affecting the production of doctrine. Those engaged in an "external critique" see international human rights law as inherently male and resistant to assimilating women's concerns into its basic framework.

${ }^{24}$ Drawing on the earlier typology, id., Karen Engle explores what happens when other cultural categories intersect with this range of women's cultures. Focusing on the issue of clitoridectomy, she argues that the critique which appears to be the most explicit in identifying a culture specific to women (the "external" critique) is the least capable of being sensitive to other non-gendened cultural contexts: Engle, Female Subjects, supra note 21 at 1518 . The external critique fails to recognize that the issue engenders deep differences of opinion, based on ethnic culture, between women. Similarly, Lama Abu-Odeh explores the difficulties of recognizing differences between women at the same time as maintaining a skepticism toward inclusive categories of womanhood, focusing on the use of the veil by feminists in Muslim countries and Western feminism's response: Lama Abu-Odeh, supra note 22. She argues that it may be possible for the two seemingly opposed positions to be reconciled at the point at which the interests of the two groups intersect. This is despite contradictions between Western feminists who see the veil as a symbol of disempowerment for women, and Muslim feminists who don it as a symbol of their power to redefine its meaning. It is not the obvious point that culture and gender can clash. Instead she locates common ground upon which feminisms meet by recognizing that although the veil increases a woman's "untouchability", id., at 1530, and thus remedies a problem of sexual harassment in the street, id., at 1531, it has a "different logic" in the workplace, where it can "seriously affect the career prospects", id., at 1534, of those who wear it. Despite (significant) differences, Islamic and Western feminist attitudes to the veil, both, through different means, seek to provide opportunities for Arab women to choose their work, and lifestyle and to be free from sexual harassment. Western feminisms are portrayed as both in opposition to, and potentially in alliance with, Islamic feminisms.
} 
problematise the issue of culture, to argue that it is no longer possible to see categories of culture, as either all the same or all different. According to this view the proposals about incorporation of difference have been superseded by a recognition that one can no longer accurately define what standard is universal or relative. Whether it be human rights standards, or indigenous art, or Coca Cola, the search for an authentically universal, or relative version of each is an idle one because, in the words of one political scientist, sameness and difference have "cannibalized" each other. ${ }^{25}$ It is the examination of this contradiction in the Newstream writings which makes the work so provocative and worthwhile.

So far we have seen how a concern with Mainstream definitions of culture permeates much Newstream work, although it is grappled with in quite different ways. A related uncertainty within the new scholarship concerns a pronounced skepticism about ever assigning people to particular cultural groups. This problem, which pervades many of the analyses, begs the question of how to ever talk about, or generalize about a group, in order to develop legal rules. The scholarship exhibits an implicit anxiety over culture which limits and complicates the possibilities of description, of law-making, and its interpretation. One response of some Newstream writers has been to argue that, despite the instability of the concept of culture, there is something intuitively appealing about representing a group of people in terms of a particular set of common characteristics, particularly when they have defined those characteristics themselves ${ }^{26}$ Implicit in this argument is the view that it would be churlish and patronizing to question the self-identification of a cultural grouping such as indigenous people.

Another response has been to argue that instead of discarding cultural groupings altogether as "untenable categor[ies] of representation", ${ }^{27}$ one needs to a reconstruct the categories of culture as they currently exist. ${ }^{28}$ The term "perspective" is used by one writer to describe a new mode of mak-

\footnotetext{
${ }^{25}$ Appuradai, supra note 15 at 17.

${ }^{26}$ Maivan Clech Lam, "Making Room for Peoples at the United Nations: Thoughts Provoked by Indigenous Claims to Self-Determination", 25 Cornell Int. L. J. 603 (1992) arguing that indigenous peoples' participation at the Working Group on Indigenous Peoples is slowly allowing for the infiltration of indigenous concerns into international norm creation. This argument explicitly utilizes the notion of culture. Lam relies on there being in existence a recognizable, identifiable cultural category of indigeneity, just as she describes her Asian community at law school in the 1970s as an "unmistakable community" defined by "rice, fish sauce, ghost stories and anti-imperialism": id., at 604.

${ }^{27}$ Annelise Riles, "Disciplines and Cultures: Perspectives on International Law and the Colonial Encounter", (1994) (unpublished manuscript, on file with author) at 10021 [hereinafter Disciplines and Cultures]

${ }^{28}$ Id.
} 
ing and interpreting law on the basis of some method other than culture ${ }^{29}$ and would entail accommodating the perspectives of a multiplicity of different groups, peoples and disciplinary approaches and a movement beyond its own boundaries into other fields such as anthropology. The inclusion of a wide range of perspectives would serve as a replacement for international law's singular reliance upon cultural forms, and the new perspectives would reflect against each other thus creating "a series of angles directed onto themselves" 30 giving rise to new ideas of law. ${ }^{31}$ So having demolished culture, as defined by intemational law, its reconstruction might be promoted by the use of a methodology other than culture. But the danger with this version of "multiperspectivalism" is that it must also ultimately be premised on one form of cultural, or perspectival, representation. It is not any more certain that the new perspectives would not replicate what was once referred to as culture. If the fit between law and culture is as constraining as Newstream writers have argued it is difficult to see how it can be escaped by a change in terminology. ${ }^{32}$

In sum Newstream work contributes to international law a sophisticated new approach to one of the basic conceptual apparatuses of the field, culture. It provides a complex rendering of definitions of culture using it to examine the inclusionary and exclusionary power of culture in doctrinal development, questions of representation of peoples, and problems of incorporating difference into law. Writers differ as to the manner in which to overcome the constraints of culture with some relying on various acts of self-will, while others argue that the nature of language, the structure of law and the problem of how to address the intersections between different categories of description make it difficult to overcome cultural definitions. On the other hand, culture may be necessary to the self-identification of peoples excluded from Mainstream processes. Ultimately no single view about culture dominates, but what emerges instead is a sometimes fraught but always provocative set

\footnotetext{
${ }^{29}$ Id. at 10017.

${ }^{30}$ Id. at 10035.

${ }^{31}$ Riles suggests that this would ultimately lead to change. "[T]he work of the discipline would be to foreground a multitude of perspectives on the perspectives that we once forced into the category of culture, and to facilitate the movement between them by representing this movement as symbolically significant": id., at 10025 .

${ }^{32}$ Ultimately perhaps the same criticism that was made of Frankenberg can be leveled also at Riles; how can one both be constrained by and transcend the categories of culture, or of perspective. Nevertheless Riles at least anticipates this criticism: id., at 10033 . She disassembles international law as culture in order to reassemble it, id., at 10036 , arguing in the process that the key feature to guide reconstructed perspectivalism is the increased participation of voices previously excluded from international law. In this respect, by selfconsciously embracing the categories she criticizes, id., at 10036, the analysis resembles Karen Knop's strategy, infra, note 129, of disassembling sovereignty and reconstructing it in a newer form taking account of the criticisms of the concept which caused it to be disassembled. While her admission lends a certain credibility to the project, it does not overcome the criticisms.
} 
of possibilities. Culture is revealed to be both a vehicle of change and of stagnation and one the redefinition of which has much to offer to Mainstream analyses of law.

\subsection{History and Sovereignty}

The second way in which Newstream work is altering one of the conceptual bases of international law is through its redefinition of the relationship between the history of international law and the doctrine of sovereignty. Newstream scholarship maintains that Mainstream international legal history is self-servingly repetitive, excessively linear in focus, unstable, and, that it conceal interests other than the purely legal. Newstream writers therefore propose various ways in which the relationship between history and sovereignty could be reconceptualized.

A central thesis of Newstream scholarship is that international law requires rewriting because the Mainstream version constantly reiterates its own history so as to present the field as a narrative of inevitable progress and modemization. ${ }^{33}$ And the telling of law's story corresponds to a range of other stories, conveniently buttressing each other, which are conventionally recounted about the same period of development. The organization of society from a tribal basis, to one based on communities and then on individuals; the movement from status to contract; and from religion to philosophy to law follow the same linear route. The development in law from a concern with substantive norms, to a focus on procedure; from legal rules to institutions; from naturalism to realism to pragmatism, all mirror the same Enlightenment story. By excluding stories which deviate from this format, international law is thus written to reflect the history of the Enlightenment in which law is constantly improved and refined with the progress of time. ${ }^{34}$

Although there is wide agreement in the new scholarship about the relationship between telling a particular history and the development of law, as with culture, Newstream writers present different versions of the Mainstream stories, and so different versions of how they could be altered. A first group

\footnotetext{
${ }^{33}$ See, e.g., Kennedy, New Stream, supra note 2 at 2.

${ }^{34}$ David Kennedy Lectures in International Law and Institutions, Harvard Law School, Fall 1994, [hereafter Lectures]. He illustrates the point by referring to a major American text which tracks a shift from a pre-modern concern with philosophy, through a classical interest in doctrine to a modern emphasis on institutions, with appropriate turning points signaled by the Peace of Westphalia in 1648, the nineteenth century rise of the nation state, and the Treaty of Versailles. See Henkin et al., supra note 4 at $\mathbf{x x i - x x x i .}$
} 
following the realist ${ }^{35}$ or sociological ${ }^{36}$ traditions, argue that international law and its history, have been constructed, ${ }^{37}$ in such a way so that something called "law" has been made, and exists at least semi-autonomously. They are not claiming that the history which is made is fictional or fraudulent but simply that it has been made, the point being to question the Mainstream version in order to show that outcomes are chosen and not inevitable. A second group however who do not share the assumption that this process of construction has lead to the existence of a separate entity called "law". Instead (and this is discussed more fully in the next section) they contend that law may be no more than a set of argumentative practices, a form of rhetoric, ${ }^{38}$ (although this does not necessarily make it any the less real or powerful).$^{39}$ So a concept like "the state", or "sovereignty" is actually about the relationship between something posited as law and something posited as society, ${ }^{40}$ rather than being a thing as such ${ }^{41}$ If law and its history are simply structures of certain repeating practices and arguments, then these tools must be questioned and unraveled, not only revealed (as the first group advocates), in order to effect any meaningful alteration in them.

Why it is that the Newstream writers would be so keen to unsettle the conventional view of history and international law? First, they argue that an examination of sovereignty reveals that the linear, historical story is wrong, and that its acceptance has skewed our current understanding of the doctrine's meaning. Far from having progressively evolved from a nineteenth century political principle, through a positivist rule early this century ${ }^{42}$ to a more nuanced concept today, Newstream writers argue that sovereignty has always

\footnotetext{
35 "Realist" is used here to describe a conception of law a result of policy choices of judges. See, e.g., Karl Llewellyn, "A Realistic Jurisprudence: the Next Step", 30 Col. L. Rev. 431 (1930).

36 "Sociological" is used here to describe a conception of law as a reflection of society. See, e.g., Roscoe Pound, "The Scope and Purpose of Sociological Jurisprudence", 24 Harv. L. Rev. 591 (1911).

${ }^{37}$ Philip Allot, "New International Law: the First Lecture of the Academic Year 20 -", in Warbrick (ed.), Theory and International Law: An Introduction (1991), 105 at 116: the "actual" is not "natural and inevitable."

${ }^{38}$ Kennedy, New Stream, supra note 2 at 9: "Law is a restatement of its imaginary relationship to society."

${ }^{39}$ One political science commentator claims "imagination has become an organized field of social practices,": Appadurai supra note 15 at 5 .

${ }^{40}$ Kennedy, id., at 6.

${ }^{41}$ Id., at 44 .

${ }^{42}$ The highpoint of positive sovereignty is conventionally represented by the holding that restrictions on sovereignty cannot be presumed: SS Lotus Case (France v. Turkey) (1927) PCIJ Ser A. No. 9.
} 
been an unstable reference point. ${ }^{43}$ For example, judicial decisions which have been traditionally interpreted as illustrative of the importance of sovereignty can equally be read as representing law's fealty to strict rules over morality. ${ }_{4}^{44}$ Moreover the meaning of sovereignty has always been in a state of flux, particularly throughout the nineteenth and twentieth century when treatise writers used the term sovereignty to describe how large trading companies wielded power over colonial territories and inhabitants ${ }^{45}$ and early judicial decisions implicitly rejected any absolute rule, developed subsequently, that restrictions on sovereignty could not be presumed. ${ }^{46}$ Later treatise writers used the concept to discuss the status of the first universal international institution, the League of Nations, arguing for example, that sovereignty was not simply about territory and power, but the moral authority wielded by government over the rights of the inhabitants, ${ }^{47}$ or that although the League lacked the critical attributes of sovereignty, ${ }^{48}$ it nevertheless possessed a separate existence which was more than the sum of its member state parts. ${ }^{49}$

A second reason Newstream writers are critical of the Mainstream representation of history is that, somewhat paradoxically perhaps, they claim it inhibits lawyers confronting current problems, because they are always look-

\footnotetext{
${ }^{43}$ Kennedy, Lectures. See e.g., David Kennedy, A New World Order: Yesterday, Today and Tomorrow [hereafter New World Order], 4 Transnational Law \& Contemp. Problems 329 (1994) at 350: sovereignty "means lots of things." Kennedy also argues that the critique of sovereignty itself has been a recurring one, Kennedy, New World Order, id., at 359, and that Newstream writers are themselves situated historically, within a "rotating critique" about sovereignty and formalism, id., at 68.

${ }^{44}$ The Antelope 23 U.S. (10 Wheaton) 66 (1825) in Deak, International Law Cases Vol. 1. Chief Justice John Marshall of the U.S. Supreme Court held that African slaves seized on a Portuguese ship had to be returned to their owners despite domestic abhorrence of slavery. The case is commonly understood as a landmark in the development of sovereignty, on the basis of respect for Portugal's sovereignty. Altematively it could be seen as an example of support for the rule of law, demonstrated in the reasoning that although "public sentiment" may wish the "unnatural traffic ... to be suppressed" this would "march somewhat in advance of strict law", id., at 3.

${ }^{45}$ Wheaton, Elements of International Law (1866) 18.

${ }^{46}$ Pacquette Habana (1900) 175 US SC Rep 677.

${ }^{47}$ Geoffrey Butler, "Sovereignty and the League of Nations", Brit. Y.B. Int'l L. (1920-21), 35. His discussion questioned any singular notion of sovereignty referring to insights from the new field of psychology, French corporations theory and recognition doctrine. According to Butler "consciousness" as much as territory created sovereignty, id., at 42 . The notion that a corporation could possess "personality" suggested that such concepts were artificial constructs, id., at 36. And the emergent distinction between de facto and de jure recognition implied that there could be different types of sovereignty, id., at 35 .

${ }^{48}$ P.E. Corbett, "What is the League of Nations?" Brit. Y.B. Int'l L. (1924) 119. Corbett lists criteria set out by Oppenheim: the right of legation, rights of sovereignty, the right of intervention for the protection of minorities, the capacity to hold a protectorate and to declare or peace, id., at 121 .

${ }^{49}$ Id., 148.
} 
ing back to past developments or anticipating an inevitably reformed future, instead of focusing upon the substantive difficulties of the present. ${ }^{50}$ The nostalgic invocation of the past ${ }^{51}$ thus has the added effect of suspending the doctrinal development of international law in the present.

What does the adoption of such a view signify in practical terms? To take one example, if intemational human rights law is perceived as constantly moving toward a more progressive state, but is instead caught in limbo between a harsh past and a utopian future, proposals to regulate the present are bound to be impeded. This prognosis can be illustrated in the ambivalence in human rights law towards the well-documented problem of violence in the home, which continues to infect most societies despite widespread condemnation. While a host of factors, such as religious belief, economic structures, and assumptions about the male right to exert power, militate against its eradication, the continued belief in the inevitability of improvements also plays a role. This optimism, often unsubstantiated by facts, blunts the impetus for change in the present by encouraging women to be satisfied that some movement is occurring and so to remain patient and passive, even if in fact conditions are worsening or remaining static rather than improving in many situations. ${ }^{52}$ Thus current realities of continuing universal abuse are hidden if international human rights law continues to passively rely upon a history in which progress is inevitable.

A third reason for the Newstream skepticism about international law history is their claim that that the Mainstream story presumes the existence of a clear demarcation between the past, in which religion, mysticism, and universalizing ideologies reigned, and the present in which society is characterized by law, rationality and the absence of ideology. ${ }^{53}$ Newstream critiques argue that religion, although largely unacknowledged, continues to inform inter-

\footnotetext{
${ }^{50}$ The field is "constantly remembering a stable origin, foreshadowing a substantive resolution, but living in an interminable procedural present": Kennedy, New Stream, supra note 2 at 2. The "stable origin" of Kennedy's claim would be states choosing to join together as a community of nations in order to create an international public order; the "substantive resolution" would be the promise of a fully developed set of substantive norms; and the "interminable procedural present" is represented by the burgeoning bureaucratic structure of the United Nations, its agencies, and other international law making institutions.

${ }^{51}$ Id., at 12.

${ }^{52}$ For a recent news article substantiating the view that violence in the home continues to be a widespread problem see, e.g., "More Women Killed in Pregnancy in US as Result of Beating Than All Other Diseases" P. Bone, The Age 24/25 Aug. 1995. For an argument claiming that economic structural adjustment policies has a disproportionately deleterious effect on women see, e.g., Marilyn Waring, "Gender and International Law: Women and the Right to Development", 12 Australian Y.B. of Int'l L. (1992) 177.

${ }^{53} \mathrm{~A}$ major casebook on international law, Henkin et al., supra note 4 at xxii , differentiates the past from the present by arguing that "universalist ideologies" of earlier times have been replaced by "co-existence" in the current period, id., at xxx.
} 
national law, because it repeats in a "secular key" religion's attitude to the sacred and profane. ${ }^{54}$ Sovereignty with its almost deified ${ }^{55}$ status within the hierarchy of norms could be one example of the operation of this distinction, because its "sanctity" continues to operate as a barrier to the development of principles perceived as incursions on it, such as human rights protection and humanitarian intervention.

A final reason to question the Mainstream linear view of history is that it buries inequalities which lie at the very foundation of some doctrinal developments. For example it is argued that sovereignty and its associated doctrines, acquisition of territory, territorial integrity, and self-determination, arose out of, reflected and reinforced the inequities of colonialism. Anthony Anghie examines the history of colonialism and its effect on the development of sovereignty doctrine. He argues that the whole project of sovereignty was a response to colonialism. He identifies two forces which were used in the name of the colonial project to oppress colonial peoples and form the structural basis for the development of the rules of sovereignty. The first arose as a response to the Austinian challenge to international law. Typically Austin's definition of law as rules emanating from a sovereign backed by force is viewed as inimical to the idea of international law itself. However the Austinian view of law also conflicts with the characterization of indigenous social orders as non-legal. Colonial peoples who, after all, would have satisfied the criterion of sovereignty had to be distinguished. Intemational law answered the latter part of the Austinian challenge, according to Anghie, by refocussing the discussion over the source of authority from the sovereign to society. If society was the real source of legitimacy it was a short step toward limiting the sorts of societies which could be such sources. Hence, argues Anghie, the response of international law was to utilize colonialism's definitions of civilization in order to exclude the "uncivilized" sources from operating as a legitimate source of sovereign authority. Once excluded as uncivilized, this exclusion then formed the basis of justifications for the development of international norms relating to sovereignty. There was a circular relationship then between the rejection of Austinian definitions, colonialism, and legal doctrine. Each reinforced the other. ${ }^{56}$

This history has continuing ramifications for international law because it has not previously been acknowledged. Newstream advocates argue that it is

\footnotetext{
${ }^{54}$ Kennedy, New Stream, supra note 2 at 17.

${ }^{55}$ Richard Ashley, and R. B. J. Walker, "Reading Dissidence/Writing the Discipline: Crisis and the Question of Sovereignty in International Studies", 34 Int'l Studies Q. (1990) 367, arguing that sovereignty has variously been reconfigured as equivalent to, inter alia. God, nature, citizen, nation, and history.

${ }^{56}$ Anghie, supra note 17 at 47.
} 
imperative for international law to excavate its foundational doctrines in order to determine whether they mask disadvantages which would counter international law's claim to impartiality and fundamental equality. So, for example, adopting a Newstream approach, one could examine whether there are inbuilt restrictions upon the application of principle of permanent sovereignty over natural resources and, if there are, whether these internal limits ought to be reassessed in the light of current understandings of equality and disadvantage? Another possibility of applying the Newstream historical approach would be to ask whether the GATT "special sector" exclusions for textiles and agriculture relate to their particular historical genesis and now require readjustment?

In sum Newstream methods of analyzing history and sovereignty have been combined in imaginative ways which suggest their application could have farreaching consequences for international law. The continuing redefinition of the relationship between history and sovereignty has been used to question the linear and progressive account of history, and the sanctity of some of law's basic principles, to uncover inequalities in doctrines, and to assist in rescuing international law from its paralysis in the face of continuing violations. The potential application of these insights in fields ranging from human rights to trade is an important project for the future. When sovereignty is no longer conceived of as natural, construction can be a liberation rather than a constraint.

\subsection{Language}

The final conceptual redefinition which Newstream introduces into international law is its focus on language as a constitutive tool of law-making. While Mainstream literature on law-making emphasizes the role of custom in the form of state practice, beliefs, and values, Newstream writers borrow from ideas associated with French post-structural theory, to argue that as law is made up of language, languages generates, rather than simply describes, legal rules.

If this view of the relationship between language and law is correct then the Mainstream approach has failed to take account of an important factor in law-making. If law is a set of arguments generated by language then it is the discussion or conversation about the arguments which creates the concepts themselves, not the actual behavior of states, their consent, or their beliefs. So Newstream lawyers refer to law to as a system of "linguistic maneuvers", 57

\footnotetext{
${ }^{57}$ Edward M. Morgan, "Internalization of Customary International Law: An Historical Perspective", 12 Yale J. Int'l Law 63, 65 (1987).
} 
or as a practice of argument ${ }^{58}$ rather than a system of rules with an a priori existence which is subsequently reduced into language.

The second aspect of this approach to language is that it disputes the Mainstream assumption that law is different from other forms of culture. If law is simply a linguistic phenomenon made up out of language, it has much more in common with other fields such as politics, or sociology, or even drama or of visual art, and therefore its claim to being unique is weakened. And so also, the things which make up the texts of law - its instruments, its doctrines, its institutions and processes - can be interpreted as aspects of any one of those fields. So for example, war crimes trials from Nuremberg, through Eichmann to Demjanjuk, can be seen as a form of legal drama, as "retributory theater" rather than as stages in the development of legal doctrine ${ }^{59} \mathrm{Or}$ a legal forum may acquire a theatrical quality. A conference on East Timor and an academic exchange to the Royal College of Madrid become scenes in a three act drama about the disillusionment of an international human rights lawyer. ${ }^{60}$ Or a particular doctrine, such as self-determination, can be interpreted in terms of its relationship to the artistic developments in the Modernist period. ${ }^{61}$

However it would be a mistake to conclude that this emphasis on law as language, or artistic narrative, reduces law to semantics or renders it any the less powerful. On the contrary the Newstream scholars depict law as a set of irreconcilable binary linguistic tendencies ${ }^{62}$ which constitute a powerful social practice $^{63}$ with very real effects. For example it is convincingly argued that the language of state sovereignty developed in such a way as to exclude colonized peoples from the benefits of sovereignty. ${ }^{64}$ Colonized groups, although

\footnotetext{
${ }^{58}$ Kennedy, Lectures, supra note 34 , describing statehood doctrine as being composed of a series of "argumentative tendencies".

${ }^{59}$ Edward Morgan, "Retributory Theater", 3 Am. Univ. J. Int'l L. and Pol. 1 (1988).

${ }^{60}$ David Kennedy, "Autumn Weekends: An Essay on Law and Everyday Life", in A. Sarat, ed., Law and Everyday Life 191 (1993) [hereinafter, Autumn Weekends].

${ }^{61}$ Nathaniel Berman, "Modernism, Nationalism and the Rhetoric of Reconstruction", 4 Yale. $J$. of $L$. and the Humanities 351 (1992). Berman aims to show how legal innovations in the inter-war period borrowed from developments in art. He argues that the principles of self-determination and minority protection fragmented sovereignty in the inter-war period in a similar way to that in which modernism fragmented representation of the body. The appearance of a principle which undermined absolute sovereignty and invested national groups with legal significance coincided with, modernism's critique of representation and its interest in primitive expressionism.

${ }^{62}$ Martti Koskenniemi argues convincingly that the entire structure of legal argument is based upon certain oppositions inherent in language. He shows that law can be reduced to two sets of mutually complementary "ascending" and "descending" sets of justifications. Martti Koskenniemi, From Apology to Utopia: The Structure of International Legal Argument (1989) [hereinafter Apology to Utopia].

${ }^{63}$ Appadurai, supra note 15 at 5.

${ }^{64}$ Anghie, supra note 17.
} 
exhibiting many of the requirements of sovereignty such as group identification, territory, political organization, and an authoritative decision maker were nevertheless not "sovereign" in the sense required by international law because they were deemed "uncivilized" according to a definition of the term which excluded non-European practices. Thus the language of law in formulating a complex spectrum of types of sovereignty determined the practice of law in a manner which made it both exclusive of non-Europeans and hierarchical toward them. Non-Europeans possessed "personality" at international law which enabled them to convey land to Europeans, and to trade with them, but nothing more. The inter-dependence between legal definitions of sovereignty and the continued subjugation of the colonized peoples is evidence of the power of language and its participation in the creation of those conditions. ${ }^{65}$ Moreover, it is evidence of the way in which the language of colonialism and international law interacted because without the language of one the other made little sense.

It is important to acknowledge however that the focus on language is not new to international legal scholarship, although the emphasis on it is. The provisional nature of the meaning of concepts such as sovereignty has long been recognized $^{66}$ as has the normative ambiguity of legal language generally. ${ }^{67}$ But the difference between the Newstream and earlier commentators is that although the latter were aware of the inherent ambiguity of the language of law they nevertheless believed that its true meaning could be extracted by going beyond the surface meaning to find an interpretation which best fitted the purpose of the instrument. ${ }^{68}$ The purpose could be located in ancillary texts, for example in the travaux preparotoire (itself a thing made up of language). Where these newer commentaries differ is in their claim that even looking behind the instrument, or doctrine will not reveal the true meaning of the law, because language, with all its normative ambiguities is still the constitutive tool. There is no escape from language. According to the Newstream approach, there will always be available a linguistic justification for a particular view of law that emphasizes either the need for sovereign autonomy and or the requirements of an interdependent world community. One may in

\footnotetext{
65 "Language cannot yield to empirical reality where it would lead to collapse of the system and of language itself': id., at 6059 .

${ }^{66}$ See discussion of the sovereign status of the League, supra notes 47 \& 48.

${ }^{67}$ Myres McDougal, Power and Policy in Quest of Law: Essays in Honor of E. V. Rostow, (1985) 145. [hereinafter, Power].

${ }^{68}$ Id., at 154: " $[\mathrm{w}]$ hen the march of events inevitably lays bare ambiguities and alternatives of interpretation. ... rationality must require that interpretation ... which best promotes the major purposes ..."
} 
certain circumstances appear more persuasive than the other, but neither is inherently or objectively correct. ${ }^{69}$

In Section 3, I have shown that Newstream scholarship has introduced some basic redefinitions of important conceptual relationships in international law between cultural form and legal doctrine, between history and sovereignty and between language and law. In Section 4 I turn to an examination of the methods Newstream scholarship uses in making these arguments.

\section{The Methodological Challenge}

Mainstream writers generally draw upon a standard range of methodological tools. Upon identifying a legal problem they classify it using a common taxonomy and common history; its textual, judicial and customary sources are discussed; the intention of the drafters or state actors is identified; as are any associated norms; and the political context or realities which constrain its interpretation. The discussion usually generates two or three possible alternatives through which the prudent scholar ordinarily divines a middle course. The objection of the Newstream to this form of analysis is that it is redundant because it simply regurgitates old problems and ultimately leads to intellectual stagnation. So in order to avoid reproducing past problems, Newstream works challenge not only the basic concepts of international law by redefining them, but also its methods. The three Newstream methods which are discussed here are the use of polarities or "doubles" to construct arguments, the personal quest device, and the focus on language.

\section{1. "Doubles"}

One Newstream strategy is to locate within international law scholarship, opposing argumentative tendencies, or, as I will call them, "doubles", in order to expose the indeterminate nature of law. Martti Koskenniemi, the best known exponent of the technique, positions international legal problems on a type of metaphorical grid in which all legal arguments veer between justifications for State behavior, or advocacy of more international regulation; between being either "apologetic" in the case of the former, or "utopian" in

\footnotetext{
${ }^{69}$ Hence Koskenniemi contends that "we cannot consistently prefer either set of arguments. Adopting a descending pattern will seem political and subjective either because it assumes the existence of a natural morality or because it creates an arbitrary distinction between States. An ascending pattern will seem political and subjective because it cannot constrain at all.... Both must be included in order to make law seem objective, that is, normative and concrete and, as such, something other than politics." Marti Koskenniemi, "The Politics of International Law", 1 Eur. J. Int'l. L. (1990) 4 at 45 (emphasis in original) [hereinafter Politics].
} 
the case of the latter. ${ }^{70}$ So examples of the apologetic, or "ascending" justification are arguments which emphasize state autonomy, the role of consent in law-making, and concreteness in legal interpretation. Typically, utopian or "descending" arguments will emphasize justice, normativity and community. By reducing legal argument to this simple but compelling structure, Koskeniemmi convincingly demonstrates the deficiencies of the Mainstream claim that law is founded in objective, rational, or value based choices and instead shows that it is part of a mutually reinforcing system of rhetoric. ${ }^{71}$

As a methodology, "doubling" is not new to international law, ${ }^{72}$ but the technique is repeated so often in Newstream methodology, that it has become a distinguishing feature or the "voice"73 of the approach. It serves a number of functions apart from exposing fundamental linguistic oppositions inherent in international law. ${ }^{74}$ Doubling shows how these oppositions may combine in order to produce legal change, ${ }^{75}$ it demonstrates how legal principles are always subject to re-interpretation because they usually contain contradictory

\footnotetext{
${ }^{70}$ Koskenniemi, id. Even the Newstream are caught in a puzzle in which they simultaneously criticize and embrace sovereignty: Kennedy, New World Order, supra note 43 at 360 . The mutual dependency of the opposing forces emphasizes again how law fits together as a structure; it is not just a series of rules but a "single rhetorical fabric", Kennedy, New Stream, supra note 2 at 38.

${ }^{71}$ This mutual dependency is referred to in 'Kennedy's work as "double movements", Kennedy, New Stream, id., at 17. So, for example, the structure of sources doctrine moves between consent and non-consent, between treaty and custom, between "getting in" to custom through opinio juris and state practice, and "getting out" via regional custom or persistent objection are defined in this way. Or, constitutional voting mechanisms at the League of Nations referred back to the politics of establishment and forward to implementation of norms, without resolution, in the same way that sources and process doctrine "produces a practice of interminable discourse.": id., at 39.

${ }^{72}$ Earlier international law commentators, probably drawing on the Realist school of jurisprudence, Llewellyn, supra note 35 , observed how doctrines "travel in opposites." Also, see e.g., McDougal, Power, supra note 67 at 156.

${ }^{73}$ Kennedy uses "voice" to refer to the style or approach encapsulated by the mainstream tradition. See, e.g., the "tragic voice of post-war public law liberalism": Kennedy, New Stream, supra note 2 at 2 .

${ }^{74}$ It facilitates the Newstream arguments about the constitutive nature of language and reveals the way sets of irreconcilable oppositions in law are themselves rooted in the structure of language. Following the argument usually associated with French post-structuralism, see, e.g., Christopher Norris, Deconstruction: Theory and Practice (1982), that language is structured into a series of binaries, law constituted by argument must also express the same oppositions.

${ }^{75}$ Sometimes these binarisms are characterized as combining with each other to create a particular legal regime. Nathaniel Berman, for example, argues that self-determination law during the inter-war period combined modernism's interest in primitivism with its experimentation with form, Berman supra note 61 . Berman illustrates his thesis by comparing the work of an artist, Picasso, with that of a legal scholar, Redslob, who wrote on nationalism. Picasso's work celebrated the period's critique of representation, and its interest in cultural expression. He fractured traditional representations of women for example and he incorporated images from "primitive" art into his work. Similarly law, described by Redslob, destabilized classic forms of concepts such as sovereignty and focused on the power of a "primitive" nationalism.
} 
impulses; ${ }^{76}$ and it lends support to the view that lawyers ought to look beyond the discipline, in order to avoid being paralyzed by these tensions. ${ }^{77}$ Moreover doubling exposes international law's reliance on irreconcilable ideas; ${ }^{78}$ illustrates the claim that Mainstream work is obsessed with procedure at the expense of achieving substantive objectives; ${ }^{79}$ and provides one important

The period's artistic emphasis on innovation with form and with technique was translated into the legal domain in new forms such as the plebiscite and minority protection regimes, id., at 375. International law of peoples, in the inter-war period, reflected a modernist alliance of two related trends, primitivism and experimentalism, id., at 369.

${ }^{76}$ The doubling method impels new interpretations by providing an impetus for the release of argumentative energy. For example, Lam, supra note 26 at 622 , examines how indigenous peoples can utilize pre-existing international law doctrine such as statehood and sovereignty to further their claim for greater participatory rights. Her primary argumentative device is to characterize statehood and sovereignty as part of a "double helix" which therefore contains "multiple inheritances" for indigenous peoples to draw upon. She relies on oppositional strands of thought which have been hidden but which are released by her analysis. Similarly, Allot describes an international law class in the twenty-first century, supra note 37, telling his students that society can either be like a poem and focus upon human consciousness, or it can be mechanistic like a motor car, id., at 109, and it is only the "joy of law" which will save it from the latter, id., at 113. It is the energy created by this contrast which inspires Allot's argument for a new normative vision of law in the current period.

${ }^{77}$ Doubling encourages writers to look outside law in order to avoid the spiral created by opposites in conflict. It encourages a questioning of law's boundaries and a dissolving of the distinctions between law and other disciplines. Newstream writers draw on anthropology, Riles, supra notes 16 and 27; art criticism, Berman supra note 61; politics, Koskenniemi, Politics, supra note 69; and feminism, Karen Knop, "Re/Statements: Feminism and State Sovereignty in International Law", 3 Transnational L. \& Contemporary Prob. 293 (1993) to help resolve the law's indeterminancies. Moreover precursors of the Newstream approach use similar techniques. So, for example, Berman relies on Redslob who argues that nationalism is informed by literature and politics, Berman, supra note 61 at 364,365 . See also Redslob's reliance on a rich background of non-legal factors to constitute a concept which has legal status, namely nationhood. Robert Redslob, "The Problem of Nationalities", Grotius Society, March $2,1931,21$. Nationalism is created as a product of various influences, including, for example, a royal family, id., at 22 , "the literary and artistic patrimony", and political instruments such as the Magna Carta, id., at 23. Interdisciplinarity, both of the analyses and or their historical sources characterizes the new approaches method.

${ }^{78}$ Ileana Porras uses the method to examine the way the Rio Declaration on the Environment contains provisions which seeks to balance seemingly incompatible goals of development and the environment, Porras, supra note 5. A sovereign right to exploit resources according to the State's own development policies, an injunction that environmental standards should reflect context, and that they should not distort trade, are included alongside provisions imposing state responsibility for environmental damage, the polluter pays principle, and a requirement that States reduce unsustainable patterns of production and consumption: id., citing Rio Declaration Principles 11, 16, 2, 16, 8 respectively. Despite what Porras calls this "paradox", id., at 21, she portrays the developments as basically healthy because they are an example of inclusion of developing countries interests, which forces developed countries to modify their practices as well as enabling developing countries to contribute to law making and interpretation.

${ }^{79} \mathrm{~A}$. function of the doubling technique is that it concretizes the Newstream arguments about the relationship between substance and process, in three ways. First, doubling emphasizes the way process avoids substance. Koskenniemi claims that classic international law developed into 
organizing device for arguments. ${ }^{80}$ In short, the use of doubles is not only characteristic of Newstream work, but facilitates the definition of many of the conceptual challenges referred to above.

\subsection{Personal Quest}

A second challenge to Mainstream method comes in the form of the personal quest device. Mainstream methods of analysis are clearly comforted by the notion that in adopting a standard methodology, as described above, one is assured that the legal conclusions which are reached are, to an extent, objective. Newstream work implicitly questions that assumption, by adopting a different set of techniques, perhaps the most controversial of which is to personalize legal issues as part of a larger quest or journey for a better international law. The quest device serves to emphasize three features: the subjective nature of law-making, the relationship between public and private, and the search for redemption within the discipline. A well known example of a writer who uses this method is David Kennedy.

Kennedy uses the quest technique to evoke the disappointment of Newstream writers with current Mainstream lawyers who, he argues, have largely inherited a pragmatic, as opposed to normative form of analysis. ${ }^{81}$ Non-legal

proceduralism in order to avoid the problem of resolving conflict either by using fundamental values or oppressive majoritarianism, Koskenniemi, supra note 62 at 128, 129. Second, it lends support to the argument that process determines substance. Kennedy claims that although state responsibility presents itself as the humble servant of substantive norms, it often supplants it, David Kennedy, International Legal Structures (1987) 175 [hereinafter: Legal Structures]. For example in the South West Africa cases Liberia and Ethiopia were refused standing on the basis of lack of interest. In this case South Africa's breach of the mandate on the grounds of racial discrimination was never resolved, but was nevertheless indirectly determined, id., at 125. Third, doubling facilitates the new approaches view that the move to process is seen as depleting substance. Tennant cautions against the dangers of indigenous peoples vesting energy in procedural reform because it may lead to valorizing process over substance; indigenous aspirations being "captured" and "co-opted" by participation, Tennant, supra note 6 at 56.

${ }^{80}$ So for example Riles' basic thesis is to show how a Europeanized version of culture ordered colonial societies, Riles, supra notes $16 \& 27$. But to make this argument she divides the mechanisms of order into opposed, but mutually dependent forces. Colonial peoples were ordered in one of two ways. Either they were ordered because they were controllable as categories of peoples deemed to lack civilization, or they were ordered by forcing them to aspire to be civilized. In both cases her argument aims to prove how international law ordered colonial peoples, and in both cases the organizing principle of her thesis is European culture in opposition to other cultures. Similarly Tennant, supra note 6 , organizes his argument around two opposing standards, his aim being to contrast one legal period with another. Indigenous peoples were represented as ignoble during the period of assimilation and as noble when autonomy was the preferred strategy. Doubling is an effective tool in ordering such an argument.

${ }^{81}$ In a thumbnail portrait of American international lawyers in the post war era, he argues that they sacrificed a doctrinal purity for institutional pragmatism and portrays them as naive 
techniques, such as a literary writing style, and the frequent use of similes and metaphors characterize the work, often as stylistic devices to repeat the theme that international law has lost its idealism and its innocence, and strayed toward realism and proceduralism. So where the emphasis is on a law of human rights which is caught between an idealistic realization of its normative framework and a realistic acceptance of its limits, Kennedy describes a human rights conference in a mood which evokes a similar equivocation and disappointment, as a "smudged Xerox affair" with a "faded agenda". 82 From the terminology we know already that the conference was held in an under-resourced field of law where the aspirations of its stated norms had a slightly soiled quality, signaling a certain weariness within the field and the inevitability or likelihood of failure ${ }^{83}$ and passive acceptance of that failure.

The personal nature of the journey is emphasized by portraying the people involved in international law-making in an informal gossipy manner, ${ }^{84}$ or by writing in the form of a personal narrative ${ }^{85}$ or as a kind of social anthropology of international lawyering. ${ }^{86}$ Again the use of the personal voice allows the Newstream writer to convey a sense of disappointment and unrequited anger about the perceived failure of Mainstream international law.

and childlike playing with toys beyond their control. There they were, "sneaking up" on sovereignty, with their enthusiasm for administration rather than rules, but their "shiny new bureaucracies failed to produce the reform which they had prophesied.": Kennedy, New Stream. supra note 2 at 4.

${ }^{82}$ Kennedy, Autumn Weekends, supra note 60 at 192.

${ }^{83}$ Metaphor is used in the same way, to repeat in stylistic mode the harsh move toward disillusionment. So in describing the way international scholarship lost its sense of direction in the post-war era, Kennedy says that its students were "invited to choose [explanations for international law] like a debutante at a smorgasbord", Kennedy, New Stream, supra note 2 at 4.

${ }^{84}$ See David Kennedy's description of the generational development of American international lawyers from the inter-war period, through the post war phase, to the present day. Kennedy describes an international law peopled by "imperialists and humanitarians", "usually Republicans", id., at 3, in the pre war era, and "Democrats eager to rebuild in the name of democracy and decolonization", id., at 4. It is a description tinged with excitement and with pathos. The inter-war characters were lawyers of "independent intellectual vision" who "rebuilt the field after the debacle of America's absence from that quintessentially progressive institution, the League of Nations", id., at 3. They are depicted as heroic if somewhat naive in ignoring the insights of realism, or the principles of the welfare state.

${ }^{85}$ David Kennedy often places himself at the center of a description. International scholarship is about personal discovery. It is also as much as about how individual people behave and act as a group as it is about the texts they write or write about. Friendships and companionability are important to this international law. Ideas and rules are not self generating.

${ }^{86}$ The same conference is described as a "site for social relations", Kennedy, Autumn Weekends, supra note 60 at 202 , even for "flirtation", id., at 205 . Much store is placed by Kennedy on the formation at the meeting of an "affinity group" id., at 204 of like minded, slightly jaded, but savvy people. 
[t]he elaborate edifice they had honored was succumbing to the erosion and fragmentation they had encouraged. Attacked from the left and right, theoretically weak, jurisprudentially behind the times, the old edifice they had so lovingly sheltered seemed hopelessly ill-equipped to the broad functions they had encouraged us to think it might perform". 87

The voice is of the disappointed disciple who had been led to believe in international law's capacity to change the international sphere and had seen those expectations dashed ${ }^{88}$ especially by those in the academy ${ }^{89}$ However it also opens the door to the Newstream to challenge its predecessors and position themselves as intellectual redeemers of the field, ${ }^{90}$ a goal which is pursued with almost missionary zeal. ${ }^{91}$ The reader witnesses the journey and is encouraged to identify with its success or failure.

The most distinctive feature of the quest is that it integrates the personal and public spheres, so that the twin themes of idealism and realism, of romanticism and cynicism, are repeated, eventually resolving into a sense of melancholy. So although a central theme of Kennedy's work is the tension in public international law between its potential to provide a strong, enforceable, normative framework and the actual limits of its application, he also seems engaged in a constant, perhaps therapeutic and quite public exploration of, what he calls, the "split moment" plified in the article about a human rights conference on the subject of East Timor. ${ }^{93}$ This is a journey which is characterized by both romance and sexu-

\footnotetext{
${ }^{87}$ Kennedy, New Stream, supra note 2 at 5.

${ }^{88}$ The sheepish exit, id., of the ancestors seems fitting as Kennedy recounts in great detail the disaster he has inherited, berating them with their many deficiencies - theoretical, jurisprudential, political and shortsighted. What is left after this rather Oedipal outburst, is only the detritus of its former proud self, "a frail dowager, too weak to withstand sustained criticism, in need of enrichment, protection and an observant fealty," id., at 6, a group whom Spiro Agnew would justifiably label "nattering nabobs of negativism," id.

${ }^{89}$ In the academy all that could be offered was "an easy patois of lazy justification and arrogance for a discipline which had lost its way and kept its jobs," id. The bitterness extended to a feeling that the teachers could provide no convincing explanation for the existence of international law as law. "We were given too many reasons to believe in international law - as our teachers struggled to make good their enthusiasm after having pawned their idealism", id.

${ }^{90}$ Not keen to keep working in the same manner, to be a "bureaucrat, a laborer in an institutional plant that no one believed was able to respond to international racism, inequality or violence," id., the younger critics commenced on a program of reinvigoration.

${ }^{91}$ Their mission, their journey was to save the field of international law, to "dislodge the discipline from its stagnation in post war realism," id.

${ }_{92}^{92}$ Kennedy, Autumn Weekends, supra note 60 at 203.

${ }^{93}$ The conference, held in Portugal in 1991, concerns the legal ramifications of Indonesia's continuing presence in East Timor. The pervasive theme of the article is the conflict between activism and realism, but this theme is conveyed through the device of the author's reminiscence
} 
ality, and by cynicism and mundaneness. ${ }^{94}$ It is a journey in which the author indulges in self-aggrandizement; ${ }^{95}$ adopts an ironic, almost flip tone; ${ }^{96}$ and attempts to shock the reader with his purported amorality. ${ }^{97}$

At one level then the writing is cynical and self-indulgent, exhibiting, albeit consciously, all the worst traits of me-generation pop psychology narration: arrogance, self-centredness, too cleverness and mock mockery. However intertwined with the heavy and quite explicit cynicism of the style is a perhaps honest, serious, funny, vaguely optimistic but sad paen to the possibilities of human rights law. Its redemptive quality lies largely in its brutal selfscrutinization and revelation. ${ }^{98}$ Moreover, the seriousness of its objectives,

upon his own participation in the conference and in the disillusionment which occurred there. His personal musings become the subject of the piece.

${ }^{94}$ Kennedy's disillusioning process of yearning for a transcendental idealistic normativity which characterized the beginnings of the East Timor conference and the cynicism and pragmatism of the Spanish nightclub, reads like the story of a failed romance. Cf. Allot's attachment to the "poetry" of international law over its mechanical qualities has a lyrical, but urgent edge to it, Allot supra note 37.

${ }^{95}$ East Timor falls away as an issue of concern or law, as does human rights or even selfdetermination. Instead we are left with an consciously indulgent personal dialogue, with a warts and all revelation of the author's misgivings, insecurities and conceits/vanities. Thus the author elevates himself as the subject of the work. He refers to himself in, what he himself labels, "messianic" terms: Kennedy, Autumn Weekends, supra note 60 at 197. At one point he is asked to provide an unscheduled interview for Portuguese television. He does so with what appears to be a general disdain for the process, for the subject of East Timor and for his audience. Subjected to questioning by a "charming reporter", he felt he "should admit that [he] had no idea what the U.S. position on Timor might be," id., at 199, but he nevertheless "wishes for a more forthcoming attitude from the State Department on Timor (don't they always disappoint)," id., at 200. He talked about the "number of crucial procedural hurdles" associated with the case and that "the case would need to be pursued diligently, but the importance of the norms involved could hardly be overstated. And so on," id. The explicit irony of the description, does not lessen its superior and condescending tone. Nowhere are the issues really aired, the whole process is treated as a sort of unpleasant but expected distraction satisfying only the subject's interest in media attention and his political detachment.

${ }^{96}$ Confessing to the reader that he was ignorant of the U.S. position in Timor, Kennedy asks "where were we on Indonesia these days anyway?" id., at 199. Small details are introduced in an irreverent tone. The author postpones his departure for the conference because he has "tickets for Natalic Cole" the preceding day, id., at 196, as if to heighten the disjunction between the hedonistic private and the altruistic public domains.

${ }^{97}$ Cogitating about whether to attend the conference, Kennedy confesses that he was motivated by reasons other than international law advocacy. He "had never been to Portugal" id., at 194, and "[a]t the very least, this sort of thing can sometimes be cashed in for political correctness points with students and colleagues," id., at 195. When Kennedy leaves the conference he flies home with a sympathetic colleague and they ruminate pretentiously over the event, creating a sort of primitive, high-altitude, concrete poetry during the flight, id., at 211-214.

${ }^{98}$ Kennedy's hyper-criticism of the nerdishness of others is easily matched by his own selfflagellation. As a participant in the conference, he fears that he is engaged (along with others) in a "great collective narcissism in the name of empathy," id., at 208. His overarching selfcriticism contrasts with the collective self-righteousness that is a product of the conference itself. 
one of which is to condemn the phenomenon of human rights conferencing as a sham, further undercuts the otherwise gratuitous flipness. ${ }^{99}$ There is tragicomedy here. Held up by a TV journalist and having no idea what the US position was on East Timor, the author "flashed rather unhelpfully on nuclear ships and New Zealand." 100 There is no question that Timor is belittled here as just another crisis. On the other hand it is the international lawyer's fate to be somewhat dilettantish, knowing a small amount about many parts of the globe and being expected to comment intelligently on them all. The speaker's shallowness becomes a reflection of the discipline's superficiality.

In short, the personal quest device allows the writer to evoke a mood of disillusionment about international law which repeats a prominent substantive theme of the work. The personal narrative style and the emphasis on the everyday behavior of people brings the discipline to life stressing the human agency involved in its creation. The ironic, sometimes aggrandizing and shocking tone of the work highlights the melancholic conclusion of the personal voyage, and the objective nature of the law-making process is further undermined. Ultimately the continual representation of law as riven by two opposing forces of idealism and realism, heightens the dramatic possibilities of the search for a resuscitated international law. ${ }^{101}$

\subsection{Language}

A final aspect of Newstream methodology is its interest in the use of language. As the last section demonstrates the Newstream style of language sometimes departs from the styles used in standard Mainstream analyses. The Newstream piece may be heavy with descriptive passages, or devices such as metaphors which are more often associated with literature than law. It may be personal and gossipy. It may contain word plays and different tones shades ranging

\footnotetext{
${ }^{99}$ When Kennedy describes himself proposing an alternative resolution to the final conference resolution it is clear that what he is expressing represents real frustration with the ineffectiveness of international law. Instead of simply calling for action which the conference participants know will not be forthcoming, he calls on the meeting to express its sheer frustration with the hopelessness of international law's prospect of real change, id., at 210 . Similarly when he refers to the Dili massacre, which occurred during the Conference, he notes how this real life incident of great magnitude barely cut in to the everyday of the conference. These are not the comments of a cynic, but of someone saddened by the disjuncture between the aims of law and its application.

${ }^{100}$ Id. at 199.

${ }^{101}$ The point of this argument, and its content, is mirrored again in the writing style. Kennedy relies on a perceived contrast between what international law should aspire to and what it had become to highlight the poignancy of the quest. In relation to the despondency of international lawyers during the Vietnam War, "either they needed a new theory of law which could account for its violation or a new theory of violation which could account for America's activity. Neither was forthcoming." Kennedy, New Stream, supra note 2 at 5.
} 
from irony to pretension, from mockery to gravity. Moreover, the emphasis on language features as both a conceptual theme and a methodology. The linguistic focus reiterates the theme of the quest when it refers to the goal of the Newstream as one of "disentangle[ment]", ${ }^{102}$ or of "translation", ${ }^{103}$ or of trying to "describe the silences" 104 . It emphasizes the conceptual theme that law is constituted by language by the use of terms which imply structure and organization, such as "taxonomies"105 and "map"106 and "architectures". ${ }^{107}$ And it sometimes translates into an open discussion of its own terminology 108 again emphasizing the self-conscious and subjective nature of the Newstream scholarship.

So in various respects Newstream work diverges from the Mainstream by introducing into international law a methodology which emphasizes doubles, is quite personal and sometimes messianic in nature, and focuses on language. The introduction of these techniques increases the transformative potential of the Newstream work by challenging the form as well as content of Mainstream analyses.

\section{The Strategic Challenge}

To this point the paper has identified a number of conceptual redefinitions and methods introduced by the Newstream to international law. Section 5 looks at one further defining feature of Newstream, namely its strategies. These are threefold: the incorporation of multiple perspectives into the lawmaking process and the contextualization of legal problems in their social, political and cultural background; the rewriting of doctrinal history; and the integration of political perspectives into legal analysis. Although not new in themselves, these strategies are applied innovatively, in a manner which reflects another difference in emphasis between Mainstream and Newstream

\footnotetext{
${ }^{102}$ Koskenniemi, Apology to Utopia, supra note 62 at xv.

${ }^{103}$ Anthony Carty, The Decay of Intermational Law (1986).

${ }^{104}$ Hilary Charlesworth, Christine Chinkin \& Shelley Wright, "Feminist Approaches to International Law", 85 Am. J. Int 'l. J. 613, at 615 (1991).

${ }^{105}$ Anghie, supra note 17 at 6051 .

${ }^{106}$ Tennant, supra note 6 at 56 .

${ }^{107}$ See, e.g., David Kennedy, "Turning to Market Democracy: A Tale of Two Architectures", 32 Harv. Int 'l. L. J. 373 (Spring 1991).

${ }^{108}$ So, for example, part of Riles' critique is to write about the appropriateness of the term "perspective" to describe her methodology, or instead to use an aural metaphor such as "polyphony", Riles, Disciplines and Cultures, supra note 27 at 10033 . Her conclusion is irrelevant for my point, which is to show how self-consciously the writers' interest in law's language is present also in discussion of their own work. The use of words to describe law, reflects that interest in structure.
} 
work. Mainstream work may utilize similar techniques, but its major aim is to facilitate the drafting of new instruments or affect changes in state practice, both of which seek to reform existing rules and practices. By contrast Newstream work is self-consciously concerned with affecting radical changes in international law, largely through the use of these three strategies, which shift the conventional emphasis from remoulding legal rules to one which attempts to reconceptualize their very bases. Although this latter goal is present only in nascent form in Newstream work, its trajectory is illustrated below.

\subsection{Incorporation of Multiple Perspectives and Contextualization}

As discussed earlier, Newstream work seeks to redefine the conceptual bases of international law. One strategy for achieving that goal is to incorporate into international legal analysis previously excluded perspectives, whether they be cultural, gender, race, social or political in nature. This technique, of the incorporation of multiple perspectives, is reminiscent of feminist and third world critiques, many of which advocate incorporation of perspectives beyond those usually included by Mainstream analyses ${ }^{109}$ (are assumed to be focused on the views of Western industrialized states).

In Newstream, as with feminist and third world critiques, the function of such a strategy is inclusive. By incorporating perspectives beyond those which are ordinarily included in law-making processes, international law will gradually be cured of any inherent biases favoring a Western or an implicitly male viewpoint. So, Newstream work argues, for example, that the culture of international law could be redefined to ameliorate its biases if it were to contain within it a "multilayering" of different perspectives. ${ }^{110}$ Comparative law, too, could be transformed by focusing on previously marginalized peoples, groups, and cultural data. ${ }^{11}$ Moreover the incorporation of multiple perspectives functions not simply as a call for a more pluralistic international law which

\footnotetext{
${ }^{109}$ For a feminist version see e.g., Charlesworth, Chinkin and Wright, supra note 104; for a third world critique, see e.g., Mohammed Bedjaoui, Towards a New International Economic Order (1979).

${ }^{110}$ So, for example, one of Riles' objectives is to show that "culture" as currently relied upon by international law is an "untenable category of representation", Riles, Aspiration and Control, supra note 16 at 21 , which omits the perspectives of the non-Western, non-European viewpoint. She proposes therefore that international law adopt an entirely new method, which she calls a "multilayering" of perspectives, id., at 36 . In this new strategy no single perspective would dominate, in the way European view of culture does in mainstream international law.

${ }^{111}$ Frankenberg also advocates a form of multi-perspectivalism, even though his basic premises are quite different from Riles', Frankenberg, supra note 8 . He is concerned with how comparative law has conducted comparisons between cultures. He derides comparative law as being a form of "tourism," id., at 412., in which the travelers/lawyers have to date been unable to distance themselves from their own assumptions about their own legal cultures; everything
} 
would simply enlarge the field of players, ${ }^{112}$ but as a strategy of destablizing many of the underlying premises of the field, ${ }^{113}$ or facilitating a rethinking of the boundaries of international legal debate. ${ }^{114}$

But despite the intuitive appeal of the argument (and the intellectual honesty of some proponents who apply the critique to their own work ${ }^{115}$ ), the main weakness of the strategy is that incorporation remains largely speculative in nature because few concrete doctrinal or theoretical examples have, as yet, been produced by the Newstream. ${ }^{116}$ Presumably however the consequences of such a strategy would be similar to those found in the field of political science. There, an incorporation approach suggests that the strategy will not be easily realized. A cultural practice cannot be automatically defined as

they see is referred back to their own world view or else they delude themselves in believing they can drop their cultural baggage: "[u]niversalism and relativism tend to reproduce the dichotomy between the self and other," id., at 415. In Frankenberg's view, the answer is for comparative law to adopt a new method which would enable it to move from the "ethnocentris$m$ " of the current approach to the "self-criticism," id., at 455 ., of his preferred approach. This strategy would involve adopting a "greater sensitivity to the relationship between the self and the other; recognizing that they are participant observers,", id., at 441, maintaining a skeptical attitude toward allegedly authentic interpretations and universal categories; and "focus[sing ... ] on the marginal stuff that is normally skipped for lack of relevance," id., at 443. Like Riles, Frankenberg expresses a similar optimism about the reconstructive possibilities of adopting a new strategy. However, in other important respects the analyses are quite different. First, Frankenberg claims that comparative lawyers participate in making their own culture, but are still observers in others, id., at 443 . Riles implicitly rejects the idea. Her work on European colonialism emphasizes that both the categories of European and non-European culture were created according to European assumptions. Second, despite Frankenberg's skepticism about culture, there are hints in the article of a belief that with the adoption of a new strategy, comparativists will be able to ultimately discover what is authentic about cultures. So, for example, Frankenberg claims it is possible to "transcend perspective," id., at 442 , as long as we recognize our participation. To Riles the idea of transcendence would be an impossibility. Ultimately Frankenberg still believes in an authentic culture, whereas Riles does not.

${ }^{112}$ Following Marilyn Strathern, id., at 28., Riles argues that this is not a matter of merely introducing more diversity into the field. Diversity still implies, contrary to her belief, that a cohesive whole could be produced whereas Riles rejects the reformist assumptions in ideas of cohesion.

${ }^{113}$ Riles portrays international law like a prism, in which the facets of the prism reflect upon each other and create a new international law based on a new series of angles or refractions of law, id., at 31 .

${ }^{114}$ Frankenberg is optimistic that if this new strategy was adopted comparative lawyers would therefore be more tolerant of ambiguity and be able to embrace a "multiplicity of developmental possibilities and explanations", supra note 8, at 454. As a result, comparative law could "imagine roads not taken, to think and explore counterfactual trajectories," id.

${ }^{115}$ See e.g., Riles who applies the strategy to her own analysis, Aspiration and Control, supra note 16 at 37, acknowledging that it may lead back to the same problems it seeks to escape - perspectivalism may be a synonym for just a different form of cultural definition. To this extent, it is a courageous tactic.

${ }^{116} \mathrm{Cf}$. Frankenberg, supra note 8 at $448-453$, who discusses the effect his approach would have on the issue of abortion. 
universal or relative, ${ }^{117}$ so that the tension between universalism and relativism cannot be resolved by a simple incorporation of interests. ${ }^{118}$ Equally, it is impossible to identify any cultural practice as entirely authentic. ${ }^{119}$ This challenge of the basic terms of cultural theory foregrounds further significant arguments for international law, for example, that legal categories such as territorial integrity, self-determination and sovereignty are uncertain, ${ }^{120}$ and that we therefore may need to develop a new theory of culture which more closely approximates scientific "chaos theory", ${ }^{21}$ than does the current paradigm. As these conclusions suggest, the incorporation of multiple perspectives by

${ }^{117}$ Applying a form of multi-perspectivalism to political analysis, Appadurai, supra note 15, finds that the simple equation of universalization of culture with Americanization no longer holds sway. An example taken from Pico lyer's work in the Philippines has a particularly eerie quality. Iyer notes that Filipinos have embraced American 1950's pop culture in a manner that is both more faithful to a Western idea of the original than the original itself ever was, and which has no connection with the conditions in which they live. Again in Riles' terms multiperspectivalism has led to unpredictable cultural combinations. A peculiarly Filipino perspective of an American past has been grafted onto the Filipino present. Thus the "hegemony of Euro-chronology "is unstable because it has created a sense of "nostalgia without memory," id., at 3.

${ }^{118}$ No cultural idea can sensibly be placed in either category in a world in which "sameness and difference cannibalize each other," id., at 17 , bringing to an end any confidence in finding a reasonable balance between the two.

${ }^{119}$ Appadurai argues that it is no longer possible to rely on an authentic version of culture. In the face of the constant dislocation between the various "scapes" (see below at $\mathrm{n}$. 121) of the global economy it is not possible for small groups, families, communities, to reproduce themselves. How does the Filipino mother or father working in Saudi Arabia and going home once every few years pass on the cultural meanings of being Filipino to their family? The process is likely to be either diluted by distance or strengthened by an artificial, but understandable resolve to hold on to what it means to be Filipino in the face of the fragmentation of the cultural group. "Trans-generational stability of knowledge... can no longer be assumed," id., at 17 Appadurai has shown how a multi-perspectival strategy demonstrates the instability of combining universality and relativity, and of culture itself.

${ }^{120}$ In the case of territory, for example, the cannibalization of sameness and difference, id., and the instability of cultural inheritance are exacerbated by "deterritorialization", id., at 11 . Mass migration, caused by war and economic dislocation, as well as use of guest-workers, separates peoples from territories. Nations and states have become "one another's projects", id,, at 13. So states seek to expound their sense of nationhood, even where it is fractured by gender, class or ethnic divides, national movements search for a State, id. The effect of deterritorialization is worsened by the media industry when canny entrepreneurs cash in on nationalistic desire to create new and sometimes fictional homelands, id., at 12. Thus the mythological homeland of Khalistan, id., at 13, has become implicated in the sometimes bloody and very real struggle of Sikhs to create a homeland. The pernicious effects of cultural, media, and territorial displacement are illustrated.

${ }^{12 !}$ Appadurai argues for a new "chaos theory" to explain what has happened to the once apparently stable idea of culture, Appadurai, supra note 102. Cultural forms are "fundamentally fractal", and that they "possess[...] no Euclidean boundaries, structures, or regularities", id., at 20 . This is because, although in the past cultural intervention occurred only through warfare or religion, id., at 1 , in the present it is mediated through five "scapes" of ethnicity, media, technology, finance and ideology, id., at 7 . The result is that culture is increasingly subject to both homogenization and heterogenization, id., at 5 . In Riles' terms then, the new perspectives 
Newstream writers, although fraught, may ultimately lead to a very different international law from one in which law reform is the major strategy for change. ${ }^{122}$

Closely associated with the incorporation technique is the strategy of contextualizing legal problems in their particular social, political or cultural background ${ }^{123}$ with a view to addressing the exclusion of non-Mainstream interests from intemational law. This is also derivative of earlier movements. Moreover in its current form it suffers from a similar deficiency, namely a lack of guidance or detail as to how it would be applied. To be effective as a strategy, the call for context ought to include a discussion of, for example, what constitutes an appropriate context, who are the legitimate decision makers and how they should be identified, otherwise it remains subject to the criticism that analyzing problems in "context" may simply introduce anoth-

are being incorporated from a variety of angles, public and private, Western and non-Western, with each incorporation and re-incorporation resulting in new "angles" and perspectives upon the existing system. So for example globalization has led to the much touted McDonaldization of culture. But even when these apparently universalized forms are transplanted into a new setting they are always modified by the indigenous culture. This has the effect of creating a global system "filled with ironies and resistances," a global "hyper-real", id., at 3. In order to better understand this potent admixture, Appadurai proposes the creation of a new theory of global cultural processes which combines both a "fractal" metaphor for shape of cultures and a "polythetic account of their overlaps and resemblances", id., at 20.

${ }^{122}$ For a fascinating discussion of a similar debate within the discipline of anthropology see Clifford Geertz, The Culture War, New York Review of Books, November 30 1995, 4 :

Anthropology is a conflicted discipline, perpetually in search of ways to escape its condition, perpetually failing to find them. Committed, since its beginnings, to a global view of human life - social, cultural, biological, and historical at once - it keeps falling into its parts, complaining about the fact, and trying desperately, and unsuccessfully, to project some sort of new unity to replace the unity it imagines itself once to have had, but now, through the faithlessness of present practitioners, to have mindlessly cast away.

\footnotetext{
${ }^{123}$ See e.g, Rosemary Coombe, supra note 7 , who is concerned with the way the intellectual property system excludes indigenous peoples' understanding of concepts of ownership and property. She argues that "supposedly...universal principles" such as authorship operate in practice to exclude native claims and lead to "injustice", id., at 267. Both intellectual property law and cultural property law rely on a system of European art and culture. Native art either falls into the category of timelessness, and thus is considered an "authentic artifact;" or it is elevated into a "masterpiece," id., 257. Art labeled authentic is protected by the newer legal regimes of cultural protection which are based on an idea of "cultural nationalism." In such cases the group is conceived of having ownership in the property which coincides with its identity as a "collective individual," id., 261. Art considered to be a masterpiece is protected by traditional copyright law. But both protections, Coombe asserts, bear traces of a form of "possessive individualism" which does not take account of the way in which indigenous peoples actually construe their association with the works of art. The only way out of this dilemma is to "listen [...] to native claims "in context," id., 266.
} 
er form of subjectivity into legal analysis. ${ }^{124}$ The danger is that "context" functions for the Newstream as "sovereignty" does for the Mainstream. One empty and amorphous concept is substituted for another.

\subsection{Rewriting Doctrinal History}

Another maneuver is to excavate the past in order to facilitate new interpretations of doctrine for the present, a strategy also reminiscent of the third world critiques of the $1960 \mathrm{~s} .{ }^{125}$ Of the strategies discussed so far, this is the most successful in the sense of demonstrating the transformative potential of Newstream work. Some examples include a reconfiguration of the doctrine of state sovereignty taking account of feminist concerns, ${ }^{126}$ the rewriting of historical accounts of sovereignty and statehood to show how they might benefit the interests of indigenous peoples, ${ }^{127}$ and a reinterpretation of a set of doctrines concerned with acquisition and personality to show that they reflect the history of colonialism. ${ }^{128}$ Utilizing either earlier legal theories, ${ }^{129}$

\footnotetext{
${ }^{124}$ See e.g., Coombe who does not convincingly avoid the charge that indigenous peoples' interests cannot be objectively identified. Instead she retreats at the critical juncture into a rhetorical statement: that "[i]t is . . . as politically dishonest to deny the objective identity of those making culturally nationalist claims as it is to assert an internationalism that privileges the nation-building imperialist enterprises of European countries", id., at 263, 264.

${ }^{125}$ See, e.g., Bedjaoui, supra note 109 , who documented the ways in which international law had disadvantaged third world interests.

${ }^{126} \mathrm{Knop}$, supra note 77 . Knop argues that a new approach to participation in lawmaking is emerging, which undermines the traditional view of sovereignty that law is made only by state consent. Although research is still to be done, it appears that the contributions of non-sovereign groups such as NGOs, or women, or environmental groups, at international fora are becoming significant factors in the making of custom.

${ }^{127} \mathrm{Lam}$, for example, shows how indigenous peoples can utilize pre-existing histories underlying international law doctrine: Lam supra note 26. Earlier I noted she does this by exploring the "double helix" of sovereignty and statehood. This enables her to reveal the "multiple inheritance" of the helix so that she can "insinuate" new concepts into the "rigidities" of the law of indigenous peoples, id., passim.

${ }^{128}$ Anghie, supra note 17.

${ }^{129}$ See Karen Knop who carefully and generously crafts an enormously diverse range of materials using and re-using earlier international legal theories: Knop, supra note 77 . She begins the process of reconfiguration by drawing upon a variety of international law and feminist sources and using them in ways probably not intended by their authors. Drawing upon Thomas Franck's claim that a right of democratic governance is emerging, id. at 301, and Fernando Teson's view that only liberal governments are deserving of the term sovereign, id., at 302, she plots the increasing trend against absolute sovereignty. (See Thomas M. Franck, "The Emerging Right to Democratic Governance", 86 Am. J. Int'l L. 46 (1992), and Fernando R. Teson, "The Kantian Theory of International Law", 92 Colum. L. Rev. (1992)). To this ingredient Knop adds the lessons of recent practice in the Balkans, showing that recognition of statehood is becoming conditional upon respect for human rights. She also draws upon the insights of the New Haven school, id., in order to argue that actors other than states contribute to the making of law. (See Myres S. McDougal et al., Human Rights and World Public Order
} 
historical inconsistencies, ${ }^{130}$ doctrinal ambiguities, ${ }^{131}$ or law-making in the form of cases, state practice, or draft conventions, ${ }^{132}$ these Newstream works compel a different understanding of foundational international law concepts, such as the relationship between women, indigenous peoples, colonialism and sovereignty. What is particularly ingenious about the examples mentioned is the way they draw upon existing raw materials (without having to resort to introducing excluded perspectives or contexts) sometimes deploying those

(1980)). Finally to these sources, she adds feminist arguments about equality, participation, and the breakdown of sovereignty. Here she outlines three models: the equality model proposed by Catharine MacKinnon, id., at note 40 , the difference formulation of Carol Gilligan id., at note 46; and the collective autonomy response of Denise Reaume id., at note 54. In relation to participation she refers to the work of Iris Young, id., at note 54, and Isabelle Gunning, id., at 312-315 (see also Isabelle Gunning, "Modernizing Customary International Law: The Challenge of Human Rights: The Challenge of Human Rights", 31 Va. J. Int'l. L. 211 (1991)). And for a feminist analysis of sovereignty, Knop draws upon the work of Jean Bethke Elsthain, id., at note 126 . The arguments lead ultimately to a reconstruction of the notion of sovereignty.

${ }^{130}$ See, e.g., Lam, supra note 26 , identifies four "conceptual rigidities" which have traditionally militated against the rights of indigenous peoples. The first is the reliance in Westphalian theory of the nation state as the perfected form of political organization, id., at 616. This, despite evidence to the contrary in countries such as Switzerland where a federated set of cantons allowed a degree of flexibility and autonomy to the different constituent groups. Second, she argues that the idea of nationhood itself was a invention. For example, at the time of the French Revolution in 1789, it is likely that there was little sense of French nationality, id., at 613. Lam quotes figures showing that eighty years after the Revolution French language was still not spoken in approximately one-fifth of the communes. Third, there is the mechanism by which indigenous peoples were excluded from participating independently in international affairs, namely the League of Nations practice of wardship, (invented as a foil to modernist understandings of cultural identity), id., at 615. Fourth, she labels as a "conceit" the idea that some subjugation, in the form of "saltwater" domination was worse than others, id., at 616. These are the rigidities she seeks to overcome.

${ }^{131}$ Anghie, supra note 17.

${ }^{132}$ Lam, supra note 26 , looks for any signs in the recent history which favor indigenous peoples' independent participation in international law and finds the following. The Western Sahara Case and the South West Africa Cases, facilitated recognition of a right of selfdetermination, id., at 618. The break-up of the former Soviet Union and former Yugoslavia were treated with "anxiety not prohibition," id., partly as a result of sympathy for national self-expression arising from the Westphalian model. Although neither instances relate directly to indigenous peoples, Lam views these developments as historical foundations for them to exploit. Moreover in 1991 the Draft Declaration on Indigenous Peoples, formulated by an expert Working Group, for the first time, included a qualified right of indigenous self-determination, id., at 620 . The Working Group also provides indigenous peoples with a forum to speak and they participate in the work of a number of UN agencies. Moreover this "interface occurs across several permeable surfaces," id., Working Group members operate on behalf of the UN and yet are also professional and independent experts. They deal with NGOs and indigenous peoples groups in a manner which has "evolved through mutual criticism, accommodation and perhaps also appreciation," id. Lam has demonstrated the continuity between the history which seemed to deny indigenous people's rights and the history of acceptance. Pre-existing histories carried with them the subversion of their own rigidities. 
sources in a manner probably not intended by their authors. ${ }^{133}$ This further demonstrates the Newstream claim above that if international law is manufactured, (in the sense of being constructed rather than fraudulent) from histories made by us, it can also "be remade by us". 134

\subsection{Integrating Politics into International Law}

Finally the Newstream advocate an international law in which political considerations are integrated in an explicit manner, another project reminiscent of realism. The political dimension is also acknowledged by mainstream scholars. The major difference is, however, that while the Mainstream writers protest that "law is politics", 135 they rarely apply that insight to their discussion of particular doctrines. Compare, for example, David Kennedy's analysis of state responsibility, ${ }^{136}$ with that of Louis Henkin et al. ${ }^{137}$ Kennedy looks at the political factors motivating what he terms the shift from substance to process, whereas Henkin et al focus upon the doctrine as a set of positive legal rules.

Newstream scholars argue that international law should not and cannot be separated from politics. ${ }^{138}$ If politics were explicitly acknowledged, ${ }^{139}$ then doctrinal biases would be disclosed. For example a purportedly neutral legal conclusion evaluating an assertion of jurisdiction over foreign nationals might be revealed to mask political considerations of national interest. ${ }^{140}$

\footnotetext{
${ }^{133}$ See, e.g., Knop supra note 77, who relies on arguments made by Teson. Although Teson rejects the view that under-representation of women derogates from the states representativeness, Knop argues that Teson's view about sovereign legitimacy provides the "rhetorical scaffolding", id., at 302, to support a feminist re-reading of sovereign will in which the low rates of participation by women in law-making lead to questions about the legitimacy consent.

${ }^{134}$ Allot, supra note 26 at 16.

${ }^{135}$ Henkin et al., supra note 4 at 1.

${ }^{136}$ Kennedy, infra note 146.

${ }^{137}$ Henkin, supra note 4.

${ }^{138}$ Koskenniemi questions the separation of international law and social life: Koskenniemi, Apology to Uiopia, supra note 62 at xiii-xvi. He argues that the only way beyond the dilemma of constantly moving between community and autonomy, between concreteness and normativity, is to abandon the idea of the objectivity of law and cease what he calls the "flight from politics", Politics, supra note 69 at 4-7.

${ }^{139}$ David Kennedy argues that international law should take more explicit account of political concerns. He says the "mantra" of the renewalists should be the "politics of private law", Kennedy, New World Order, supra note 43 at 374, or, in another piece that international economic law fails to answer "traditional questions about the politics of international law, David Kennedy, "The International Style in Postwar Law and Policy", 194 Utah L. Rev. 7 (1994) 101 [hereinafter The International Style].

${ }^{140}$ See e.g., Robert Malley, Jean Manas, Crystal Nix, "Note: Constructing the State Extraterritorially: Jurisdictional Discourse, The National Interest, and Transnational Norms", 103 Harv. L. R. 1273 (1990) for an analysis of the doctrinc of reasonableness as it relates to questions
} 
Or analysis of the development of a particular doctrine, such as acquisition, would show it to be hamstrung by political, rather than legal, concerns. ${ }^{141}$

The Newstream strategy of integrating politics into law claims to expose law's silence about politics, cast doubt upon its objectivity, and facilitates the identification of underlying biases within doctrine. And it demands that international lawyers identify the politics they pursue through international law. Once the political ramifications of doctrine are revealed, the retreat into proceduralism seems no longer possible.

In Section 5 three strategies for change arising out of new approaches scholarship have been identified. Multiplicity and contextualisation address law's exclusionary power, and rewriting doctrinal history and integrating political concerns upset its constructed and discriminatory categories. To this point the approach appears to have developed the tools for changing much that it criticizes. Why then does it sometimes fail to do so?

\section{Recurring Problems and Conclusion}

In this conclusion I will focus on some recurring problems with Newstream analysis. I will argue that the content of the critique can be marred by, inconclusiveness, reductiveness and equivocation, and that the style suffers from a sometimes disengaged or patronizing tone.

\subsection{Inconclusiveness, Reduction and Lack of Concretization}

Newstream critiques frequently seem to pull back from the brink of affecting real change in international dialogue. For example the consequences of alter-

of jurisdiction. They show that when the United States Supreme Court engages in a balancing process to assess the "reasonableness" of allowing another state to assert jurisdiction over an American national, the Court is actually concerned with how the assertion of jurisdiction will affect American national interests, id., at 1297 . Thus the political question of national interest trumps a supposedly neutral legal question. They show that reasonableness doctrine masks the political consequences of power differentials between states.

${ }^{141}$ See e.g., Carty, supra note 103 at 43-60. Carty examines how political considerations have affected the development of a particular legal doctrine. He claims that despite its apparent formality, the law of acquisition is a highly politicized concept. He demonstrates this by examining how the whole edifice of the law of acquisition is based upon Roman notions of possession of land, and a capitalist conception of commodities exchange. He argues that the influence of these two political factors foreclosed the development of self-determination and permanent sovereignty over natural resources, both of which are doctrines concerned with method of use, not exchange, id., 51-60. For another discussion of the politicized nature of acquisition doctrine with particular application to Australian Aboriginal ownership of land, see also Gerry Simpson, "Mabo, International law, Terra Nullius and the Stories of Settlement: An Unresolved Jurisprudence", 19 Melb. Uni. L. R. (1993) 195. 
native strategies of changing international law are never fully explored, ${ }^{142}$ arguments about what is actually wrong with international law are inconclusive, ${ }^{143}$ or fail to speculate about the conditions which might affect a change in the Mainstream perspective. ${ }^{144}$ Moreover the Newstream calls for the integration of politics with law is not sufficiently problematised. The call is a commendable ambition but doubts remain. There is a tendency in some Newstream work for an apparently radical critique to conclude with a facile or reductive call for a move to politics, yet the political is as contested and enigmatic as the legal. While concepts such as sovereignty are being denigrated as too incoherent to underpin the legal system, a radically pluralistic politics seems an inauspicious place to find new normative consensus.

Other Newstream scholars are intemally inconsistent calling, for example, for changes in Mainstream analysis while not acknowledging that the critique must apply to Newstream analysis as well ${ }^{145}$ while others labor under a

\footnotetext{
${ }^{142}$ For example, there is something dissatisfying about being left with only the conclusion that the strategy of multi-perspectivalism will lead to a "discomforting" but "instructive void," Riles, Discipline and Cultures, supra note 27 at 740 . It is this rather vague but vaguely engaging image which is at once the most exciting and frustrating aspect of the strategy proposed. Thus despite the intuitive appeal of the analysis, the strategy as a technique to actually change the operation and description of international law, remains largely unexplained. Riles provides no definite idea of what she means by putting new perspectives together and no concrete examples of doctrinal changes which might result. While complete specificity is not required, some hypotheses about how the strategy would apply ought to have been explored. In the absence of this the consequences of this maneuver remain somewhat speculative. What would be produced by a new melange of perspectives relating to each other in new combinations and permutations? By admitting that she does not know what exactly would be produced or how these new perspectives would relate to each other, or indeed even whether they would not replicate an idea of culture, Riles withdraws from prescribing an effective application of the strategy. This last step is crucial if the incorporation of multiple perspectives strategy is to have any effect on conventional perceptions of the international. In contrast, Appadurai, supra note 15 , is able to demonstrate not only that cultural meanings are unstable and thus must be reinterpreted with the incorporation of new perspectives, but that this process will itself lead to new instabilities. New cultural classifications will feed off each other complicating the possibility of simply improving the current system by incorporating new perspectives. American culture suffers from this defect as much as any other, and the resulting chaos is what defines culture in the late twentieth century.

${ }^{143}$ See e.g., Kennedy, who analyses the common intellectual history of new approaches with earlier schools but ends only with an abrupt and sketchy call for the renewalists to differentiate their critique by examining redistributive consequences and private law, Kennedy, New World Order, supra note 43 at 374-375. Similarly, when discussing international economic law, it is not until close to the end of the article that he explicitly states what he believes is wrong with a regime infused with the spirit of liberal trade policy, namely, that it might fail to answer political questions about how the world trading system disadvantages developing countries, or structures the debt crisis, Kennedy, The International Style, supra note 140 at 101, 102.

${ }^{144}$ See the discussion of culture and change accompanying notes 125-127.

${ }^{145}$ See e.g., Frankenburg, supra note 8 , who fails to recognize the contradiction in criticizing the Mainstream for not taking account of perspective and then entreating us to trying overcome perspective.
} 
suffocating equivocation or unwillingness to evaluate specific legal claims. ${ }^{146}$ The reader's expectations are constantly thwarted by these retreats as the critiques seem to peter out just as they are beginning to bite and the potentially transformative moment is lost, leaving impressive descriptive analyses lacking in effect. ${ }^{147}$

\subsection{Equivocation, and Condescension}

Newstream work is also dogged by recurring stylistic problems which inhibit its more widespread application. The equivocatory tone of some critics leads to a voice which seems disengaged and at odds with the general call for a more involved politics. ${ }^{148}$ There is a tendency to patronize ${ }^{149}$ other actors making assumptions about what will be the outcome of adopting a particular strategy. A superior condescending tone is used ${ }^{150}$ in characterizing other interna-

\footnotetext{
${ }^{146}$ Kennedy, e.g., argues that state responsibility process doctrine, avoids and supplants substantive outcomes but withdraws from making a normative judgments, Legal Structures, supra note 79. So the International Court's reliance on standing in the South West Africa Cases, to preclude considering the merits of apartheid as a breach of self-determination, is an example of the oscillation within international law between substance and process. But at the conclusion of his argument, the oscillation is described as one of the "strengths": Kennedy, id., at 191, of the discipline, leaving the reader to ponder whether a strength which had appeared to lead to injustice is a good or a bad strength. Even if Kennedy is arguing that indeterminacy opens possibilities for argument, the illustrations used seem to demonstrate that oscillation is not a positive outcome.

${ }^{147}$ Not all Newstream writers suffers from this deficiency. Some demonstrate why, as Riles predicts, the void might be instructive, Riles, supra note 16 at 740 . So, for example, when Abu-Odeh locates the intersection between Islamic feminism and Western feminisms' shared concens about equality, regardless of conflicting attitudes to the veil, she signals an enrichment of Western feminism if it better understood the complex conception of veiled sexuality in Islamic culture, Abu-Odeh, supra note 22 at 66 . When a Toronto conference summary introduces the voices of women who have traditionally not been heard in Western feminist human rights, we begin to see what benefits multi-perspectivalism might bring, Rebecca Cook, "Women's International Human Rights: The Way Forward", 15 Human Rights Quarterly 230 (1993) 231-261.

${ }^{148}$ As one proponent comments, the method often "fails to provide answers" and that "skepticism about the material determinacy of international law seems to prevent new approaches lawyers from making normative propositions," Koskenniemi comment in Kennedy \& Tennant, supra note 2 at 427.

${ }^{149}$ See, e.g., Tennant's argument, supra note 6, that even if participation is the goal which indigenous peoples desire, the writer assumes that it will lead to co-option. Surely if selfdetermination and participation have any meaning it is that the groups asserting their rights have the right to determine when and how they will utilize them. Lam is also mindful of the dangers of participation, but claims that it has led to concrete substantial goals such as realization of limited forms of self-determination: Lam supra note 26 at 617-618. She also notes that participation can be an end in itself.

${ }^{150}$ For e.g., the personal quest device of Kennedy, Autumn Weekends, supra note 60 at 202, while effective in some respects, also carries with it certain risks of condescension. It exposes a tendency on the part of some writers to denigrate the contributions of other participants in the
} 
tional legal actors, and some disparage Mainstream strategies for change as ineffective without sufficient explanation. For example, it is not clear that participation has only procedural consequences, ${ }^{151}$ or that substance is always "strong" and procedure inevitably "weak". This latter propensity to adopt a substance/procedure dichotomy in the belief that the former is strong and the latter is weak, pre-empts the reader's capacity to assess the issue. Apart from the very difficult question of whether such a content/form distinction does exist, it is a somewhat reductive way of characterizing legal practices which tells us little about the actual nature and content of the practice. Sometimes it appears to be a kind of shorthand for good and bad, rather than a useful or revealing comment upon a practice. The dangers of condescension and reductionism then, are that they trivialize, oversimplify and obscure a serious and elaborate intellectual agenda for change. These problems and others iden-

international sphere. For example, at a plenary where a "fashionable Latin American Woman ... in rather high pumps" id., suggests a reformatting of a conference resolution, Kennedy comments that:

We all knew we should clearly distinguish the perambulatory recitation of norms and facts from the operational engagement with the everyday. Numbering would do the trick, indentation would help, id.

Portraying the woman's concerns as mere cosmetic artistry he reduces their importance and trivializes her contribution. The mocking tone permeates the entire recollection. By the time the final conference session arrives Kennedy muses on "enjoy[ing] the hilarity of voting as a bloc on one after another absurd amendment or proposal", id., at 209. The flippant tone of the description conveys a condescending attitude by the writer to the other participants. Personal and probably hurtful details are included. The constitution-drafting group is described as a "distinctly dull crew of Pedro's more earnest Portuguese acquaintances," id., at 199, and "the last refuge of the lawyer's lawyer, the nerd's nerd," id., at 201. The bitchy throwaway lines heighten the sense that unnecessary details are included at others' expense. The reader hovers endlessly between laughter and alienation.

${ }^{151}$ Tennant, supra note 6 at 50-55, is skeptical, or at least cautious, of the gains that would attend increased indigenous participation in lawmaking claiming that this participation valorizes process over the achievement of a substantial goal. He argues that the misrepresentation of indigenous peoples by international law (discussed above), led indigenous peoples to resist these images. That resistance has led them to argue for increased rights of participation in international law making processes. Tennant argues that although participation seems to be a worthwhile goal, it carries with it the danger that indigenous peoples will be co-opted by becoming part of the institutional process. "The danger lies in the shift from substantive political goals to the procedural goal of increased participation," id., at 50 . The weaknesses in his argument are characteristic of new approaches work. First, it is not clear why increased participation, even characterized as a procedural rather than substantive goal, is not a desirable end in itself. In respect of other groups excluded from international law-making, the claim is often made that their increased participation will provide an opportunity to create norms which incorporate the concerns of those groups: Gunning, supra note 129. Second, there is some room for argument as to whether participation is simply procedural, and whether that label condemns it in any case. 
tified throughout the discussion above have the ultimate effect of diminishing the influence of the new scholarship on the discipline generally.

This paper has sought to make explicit a debate within international law between two schools of thought labeled Mainstream and Newstream. It has argued that the Newstream critique has emerged as a significant body of criticism, with common themes, methods, and strategies aimed at redefining what it perceives as Mainstream forms of analysis. In disclosing some of the deficiencies and gaps of international law, Newstream work, is developing into a well crafted body of scholarship. It has dissected the way in which law constructs its own histories, is inherently indeterminate, masks distributive disadvantage, is decontextualised, and excludes a range of perspectives. As a first stage of any analysis, the critique has demonstrated its potential to renew and invigorate international legal doctrine. It is provocative and sometimes daring work.

Accurate and incisive dissection and description is critical to any project of transformation and if the point was to show that traditional legal analyses were demonstrably partial, exclusive and biased then this has been achieved. A critical descriptive and expositive function has been performed. But the Newstream works seem to aim to do more. They advocate change, contextualization, multiplicity, and politics. And it is this transformative potential of the critique that remains unrealized. In fact reading new approaches work can be a baffling experience, with frustrating results. The analyses lack concretization, and tend toward reductionism and condescension with the consequence that what is potentially transformative risks becoming rather unappealing. ${ }^{152}$ Change is merely flagged as something which would eventuate if these techniques were adopted within the Mainstream. To paraphrase one of the its repeated themes, the critique itself remains suspended in an interminable present between the description of what has come before and the promise of what its implementation will bring. ${ }^{153}$ So although Newstream work highlights previously untapped but important anxiety over what is culture; displays a fascination with the relationship between history and sovereignty; and a deep interest in the narrative structure of law; applies new methods and reinvigorates old strategies, creating opportunities for reading old material in new ways, to date it has led to an utterly altered vision of what international law is but not what international law could be.

\footnotetext{
${ }^{152}$ There is an almost poignant lack of communication between the Newstream and traditional international law. A mixture of antipathy and condescension exists between the two groups resulting in a dialogue of the deaf.

${ }^{153}$ David Kennedy constantly refers to an oscillation, within traditional analyses, between substance and process, Kennedy, New Stream, supra note 2 at 17.
} 
Ultimately though the measure of its success may be its commitment towards enunciating another kind of international law, a commitment which is symbolized in the quest device which characterizes most of the major works. ${ }^{154}$ Like all quests, it is characterized by a sense of sadness for what current international law has lost. Moreover what differentiates it from earlier commentators' similar journeys, ${ }^{155}$ is the central, self-appointed, almost messianic role of the new international lawyers. Exploiting the drama of the search, the Newstream international lawyers place themselves at the center of the quest, exhibiting an almost heroic urge to save international law, and themselves, from the moral bankruptcy of indeterminate material outcomes. ${ }^{156}$ This is the goal. But although the search and its quixotic conclusion have echoes in the modern period, the quest is all the more poignant for the postmodern realization that there can be no return either to the weak realism of the earlier phase, or to an even earlier faith in natural order. It is this melancholic view of the traditional discipline which impels the journey toward new forms of scholarship.

\footnotetext{
${ }^{154}$ For example, Allot is on a joumey through "consciousness": Allot supra note 37 at 109; Koskenniemi tracks the trail of the disappointed jurists who "put their faith variably on logic and texts, history and power ...": but who lost their footholds; Koskenniemi, Politics, supra note 69 at 31, Kennedy deplores the "tragic voice of post-war public law liberalism": Kennedy, New Stream, supra note 2 at 2 ; and Carty is escaping international law's "decay", Carty, supra note 103.

${ }_{155}$ McDougal, supra note 67 at 156-157.

${ }^{156}$ Koskenniemi, Apology to Utopia, supra note 62 , passim.
} 
This text is taken from Traversing the Divide: Honouring Deborah Cass's Contributions to Public and International Law, edited by Kim Rubenstein, published 2021 by ANU Press, The Australian National University,

Canberra, Australia.

doi.org/10.22459/TD.2021.13 